Prepared in cooperation with The Nature Conservancy, Washington State Department of Ecology, and U.S. Environmental Protection Agency

\title{
Geospatial Assessment of Ecological Functions and Flood-Related Risks on Floodplains along Major Rivers in the Puget Sound Basin, Washington
}

Scientific Investigations Report 2015-5033 



\section{Geospatial Assessment of Ecological Functions and Flood-Related Risks on Floodplains along Major Rivers in the Puget Sound Basin, Washington}

By Christopher P. Konrad

Prepared in cooperation with The Nature Conservancy, Washington State

Department of Ecology, and U.S. Environmental Protection Agency

Scientific Investigations Report 2015-5033 


\title{
U.S. Department of the Interior SALLY JEWELL, Secretary
}

\section{U.S. Geological Survey \\ Suzette M. Kimball, Acting Director}

\author{
U.S. Geological Survey, Reston, Virginia: 2015
}

For more information on the USGS - the Federal source for science about the Earth, its natural and living resources, natural hazards, and the environment, visit http://www.usgs.gov or call 1-888-ASK-USGS.

For an overview of USGS information products, including maps, imagery, and publications, visit http://www.usgs.gov/pubprod

To order this and other USGS information products, visit http://store.usgs.gov

Any use of trade, firm, or product names is for descriptive purposes only and does not imply endorsement by the U.S. Government.

Although this information product, for the most part, is in the public domain, it also may contain copyrighted materials as noted in the text. Permission to reproduce copyrighted items must be secured from the copyright owner.

Suggested citation:

Konrad, C.P., 2015, Geospatial assessment of ecological functions and flood-related risks on floodplains along major rivers in the Puget Sound Basin, Washington: U.S. Geological Survey Scientific Investigations Report 2015-5033, 28 p., http://dx.doi.org/10.3133/sir20155033.

ISSN 2328-0328 (online) 


\section{Contents}

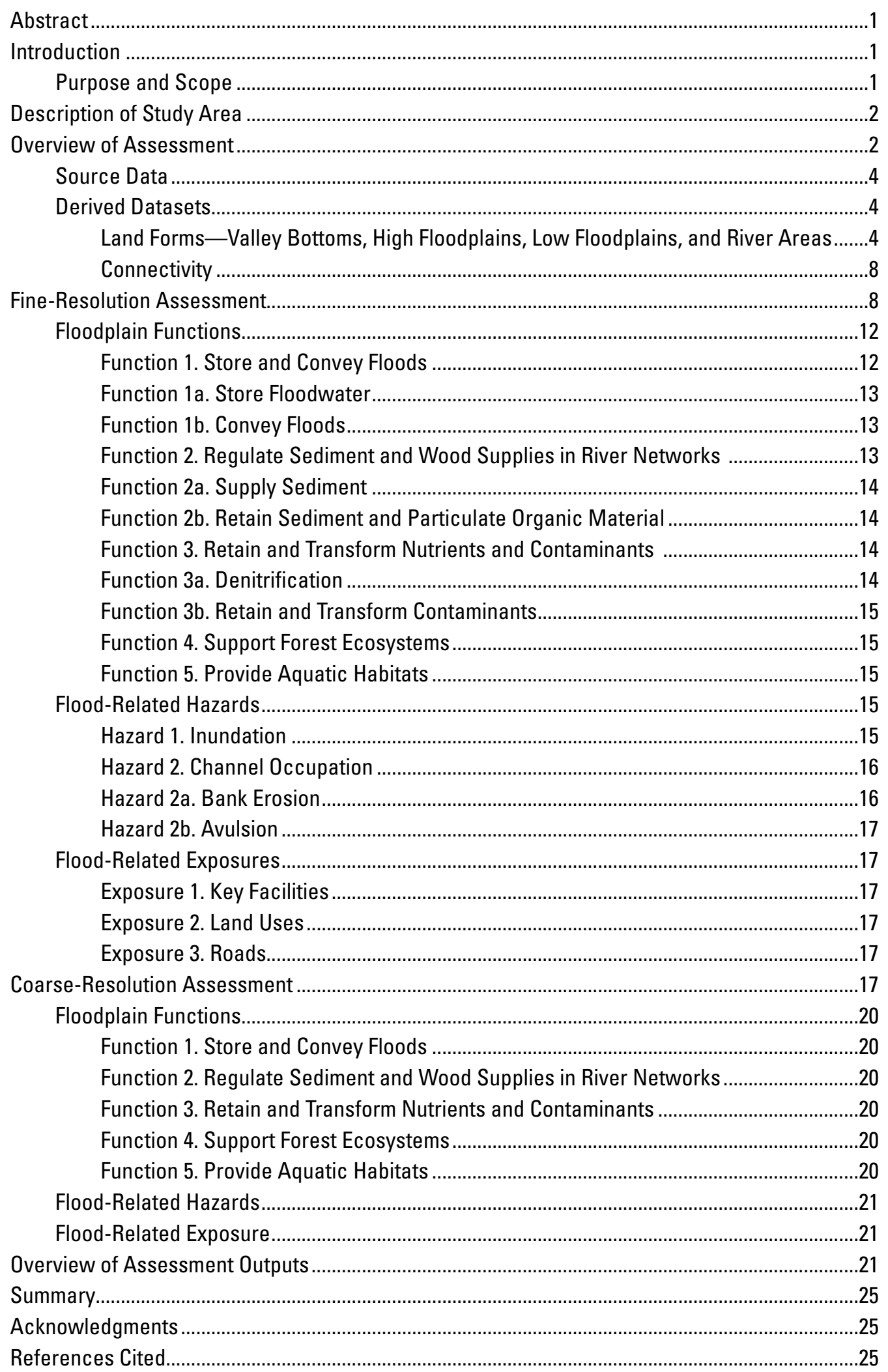




\section{Figures}

1. Map showing major river networks and valley bottom areas in the Puget Sound Basin, Washington.

2. Graph showing change in stage from median daily stage for the 50th and 90th percentiles of annual maximum stage as a function of drainage area at 40 U.S. Geological Survey streamgaging stations on unregulated rivers without levees with at least 10 years of daily stage records, Puget Sound Basin, Washington

3. Pie diagram showing connectivity and development of floodplains in Puget Sound Basin, Washington

4. Graph showing width of connected floodplain area as a function of drainage area for mainstem rivers in the Puget Sound Basin, Washington...

5. Graph showing length of confined and unconfined mainstem rivers in the Puget Sound Basin, Washington

6. Graph showing cumulative floodplain area for fragment sizes, Puget Sound Basin, Washington

\section{Tables}

1. Source datasets used in the geospatial assessment of ecological functions and flood-related risks on floodplains along major rivers, Puget Sound Basin,

Washington

2. Derived datasets used in the geospatial assessment of ecological functions and flood-related risks on floodplains along major rivers, Puget Sound Basin, Washington.

3. Summary of models and outputs used for fine-resolution (10-m) assessment of floodplain function, hazard, and exposure, Puget Sound Basin, Washington

4. Attributes of floodplain units used in the geospatial assessment of ecological functions and flood-related risks on floodplains along major rivers, Puget Sound Basin, Washington

5. Indices of floodplain function and risk used in the geospatial assessment of ecological functions and flood-related risks on floodplains along major rivers, Puget Sound Basin, Washington.

6. Summary of floodplain connectivity and land use resulting from the geospatial assessment of ecological functions and flood-related risks on floodplains along major rivers, Puget Sound Basin, Washington. 


\section{Conversion Factors}

[International System of Units to inch/pound]

\begin{tabular}{lcl}
\hline \multicolumn{1}{c}{ Multiply } & By & \multicolumn{1}{c}{ To obtain } \\
\hline meter $(\mathrm{m})$ & Length & \\
kilometer $(\mathrm{km})$ & 3.281 & foot $(\mathrm{ft})$ \\
& 0.6214 & mile $(\mathrm{mi})$ \\
\hline hectare $(\mathrm{ha})$ & Area & \\
square kilometer $\left(\mathrm{km}^{2}\right)$ & 2.471 & acre \\
\hline
\end{tabular}

\section{Datums}

Vertical coordinate information is referenced to the North American Vertical Datum of 1988 (NAVD 88).

Horizontal coordinate information is referenced to the North American Datum of 1983 (NAD 83).

Elevation, as used in this report, refers to distance above the vertical datum. 



\title{
Geospatial Assessment of Ecological Functions and Flood-Related Risks on Floodplains along Major Rivers in the Puget Sound Basin, Washington
}

\author{
By Christopher P. Konrad
}

\section{Abstract}

Ecological functions and flood-related risks were assessed for floodplains along the 17 major rivers flowing into Puget Sound Basin, Washington. The assessment addresses five ecological functions, five components of flood-related risks at two spatial resolutions-fine and coarse. The fine-resolution assessment compiled spatial attributes of floodplains from existing, publically available sources and integrated the attributes into 10-meter rasters for each function, hazard, or exposure. The raster values generally represent different types of floodplains with regard to each function, hazard, or exposure rather than the degree of function, hazard, or exposure. The coarse-resolution assessment tabulates attributes from the fine-resolution assessment for larger floodplain units, which are floodplains associated with 0.1 to 21-kilometer long segments of major rivers. The coarse-resolution assessment also derives indices that can be used to compare function or risk among different floodplain units and to develop normative (based on observed distributions) standards. The products of the assessment are available online as geospatial datasets (Konrad, 2015; http:// dx.doi.org/10.5066/F7DR2SJC).

\section{Introduction}

Floodplains are a vital part of the ecological and social landscape in the Puget Sound Basin. Ecologically, floodplains support diverse and productive biological communities that inhabit riparian forests, wetlands, and river channels. Culturally, large river floodplains have been a focus for fishing, hunting, human settlement, and agriculture because of an abundance of fish and wildlife, fertile soils, level land, and access to water. The ecological and cultural significance of floodplains compels floodplain managers to improve ecological function while reducing flood-related risks to people. This assessment presents geospatial information about ecological functions and flood-related risks along 17 major rivers in the Puget Sound Basin that can be used to facilitate integrated management of floodplains for multiple objectives.

\section{Purpose and Scope}

Five ecological functions and five components of risk to people living on and using floodplains were assessed along major rivers in the Puget Sound Basin. The assessment integrates spatial information about factors that contribute to each function and risk component. The output can be used in a geographic information system (GIS) to identify locations to protect or recover ecological functions, to reduce risks, and to understand the types of actions that likely are required to achieve those objectives.

Floodplains support many ecological functions, which range from basic services, such as storing sediment and acting as the physical template for riparian and aquatic ecosystems, to more integrated processes including population dynamics, trophic exchanges, and community succession (Wolman and Leopold, 1957; Ward and others, 2002; Naiman and others, 2010). Although floodplain restoration depends on the suite of all ecological functions provided by floodplains (National Research Council, 1992), integrated floodplain management may focus on improving individual functions depending on management priorities. The assessment addresses five basic functions of floodplains:

1. Store and convey floods;

2. Regulate sediment and wood supplies in river networks;

3. Retain and transform nutrients and contaminants;

4. Support forest ecosystems; and

5. Provide aquatic habitats, particularly for threatened and endangered salmonids.

These functions were selected for three related reasons. They accommodate a range of ecological objectives for the floodplain manager. Individually, each function can provide a benefit in settings where comprehensive floodplain restoration may not be possible. The assessment of these functions can be based on a categorization of a limited number of key factors rather than requiring a more sophisticated integration of many factors into a quantitative estimate of functionality. 
Cultural activities on floodplains present flood-related risks in the Puget Sound region. Generally, risk can be assessed in terms of its constituent components including hazard (physical process that causes damage), exposure (people, property, or activities that are impacted by the hazard), vulnerability (severity of damage when the hazard occurs), and resilience (capacity to recover after the hazard occurs). This assessment provides information about two flood-related hazards and three forms of exposure of people to those hazards:

1. Inundation hazards;

2. Channel occupation hazards;

3. Key facility exposure;

4. Land use exposure; and

5. Road exposure.

Vulnerability and resilience of human activities on floodplains are outside the scope of the assessment.

Functions and risks are assessed in terms of categories representing distinct combinations of factors contributing to each function or risk rather than a continuous scale of the level of function or risk. The categories can be used to infer the broad types of management actions required to improve function or reduce risk, such as reconnecting floodplains or providing flood protection for agricultural practices.

This assessment is structured on geospatial data that are available for major river valleys in the Puget Sound Basin. A comprehensive assessment of function and risk would require additional information about floodplains and development of methods for integrating that information, which are outside of the scope of this assessment. Determination of floodplain function, flood-related hazards, or human exposure to flood-related hazards at specific locations requires additional investigation (for example, Rapp and Abbe, 2003; Latterell and others, 2006; Konrad and others, 2008; Olson and others, 2014; U.S. Army Corps of Engineers, 2014). Discrepancies between this and other assessments should be expected because of the simplified methods and resolution of data used in this assessment. Without verification of the assessment results, deference should be given to site-specific information or more detailed analyses of functions and risks at particular locations.

\section{Description of Study Area}

The Puget Sound Basin covers $36,700 \mathrm{~km}^{2}$ in western Washington State and the Province of British Columbia that drain to Puget Sound and the Strait of Juan de Fuca (fig. 1). The basin is bounded by the Cascade Range to the east and the Olympic Mountains to the west. The southern boundary of the basin is defined by the divide between the Chehalis
River (outside of Puget Sound Basin) and the Nisqually and Deschutes Rivers (inside of Puget Sound Basin). Puget Sound is bounded to the west by the Strait of Juan de Fuca at Admiralty Inlet. Areas along the northern coast of the Olympic Peninsula to Cape Flattery, the San Juan Islands and areas west of the Cascade crest from the Skagit River to the international border with Canada typically are included in the Puget Sound Basin for regional planning (Washington State Department of Ecology, 2013a).

This assessment covers the valley bottom areas of the 17 largest rivers in the basin-Nooksack, Samish, Skagit, Stillaguamish, Snohomish, Cedar, Green-Duwamish, Puyallup, Nisqually, Deschutes, Skokomish, Hamma Hamma, Duckabush, Dosewallips, Big Quilcene, Dungeness, and Elwha. Valley bottoms are defined as areas where the land surface is less than $10 \mathrm{~m}$ above the elevation of the river extrapolated across the valley and includes alluvial deposits filling valleys (Washington Department of Natural Resources, 2010) and Special Flood Hazard Areas (SFHA) with less than a 0.01 annual probability of flooding (Federal Emergency Management Agency, 2013). The study area extends up the networks of these rivers to include the valleys of tributaries that drain more than $50 \mathrm{~km}^{2}$. The total length of major rivers and tributaries in the assessment is $3,290 \mathrm{~km}$. Floodplains associated with small rivers and with streams draining directly to Puget Sound and streams in the 17 major river basins that have a drainage area less than $50 \mathrm{~km}^{2}$ are not included in this assessment.

The assessment area spans both mountain and lowland valleys, which have distinct geologic histories in the Puget Sound Basin. Mountain valleys in the basin were formed by a combination of alpine glaciers and incision by rivers. Lowland valleys were carved by continental glaciers and subsequently filled by glacial and fluvial sediments. Collins and Montgomery (2011) describe a typology for valleys in the Puget Sound region that further distinguishes lowland valleys filled by glacial or post-glacial (fluvial) sediments and implications of these distinct histories for channel dynamics.

\section{Overview of Assessment}

This assessment compiles and derives spatial information on factors affecting ecological functions and flood-related risks to people on floodplains. Floodplain functions and risks depend on local conditions, such as topography and land cover, but also the larger floodplain system that extends laterally across a valley, and the position of the floodplain in a basin. To address the influence of factors at different scales, the assessment is implemented with two resolutions - fine and coarse. The fine-resolution assessment integrates physiographic and cultural attributes of $10-\mathrm{m}$ cells to assess local conditions affecting function and risk. 


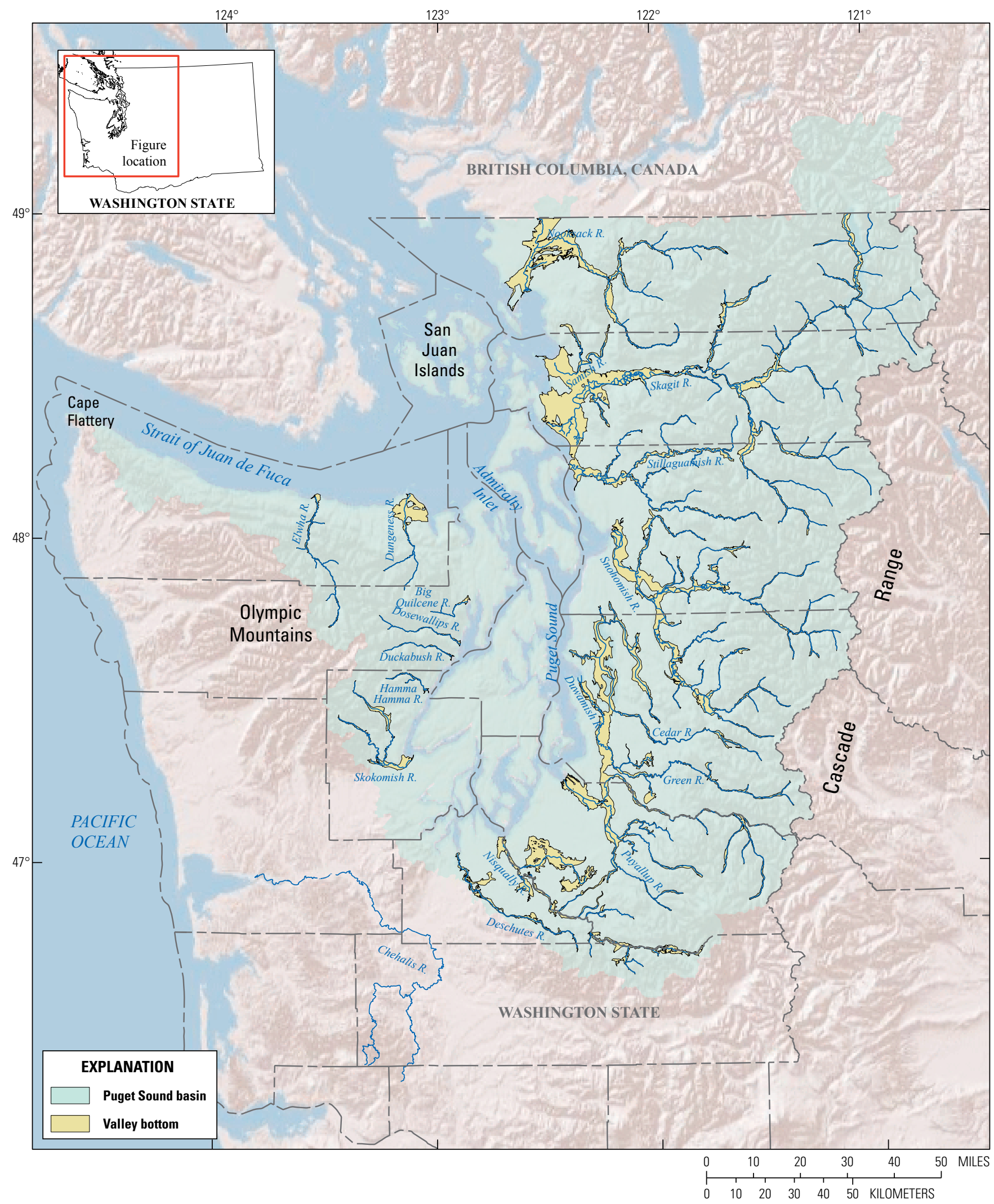

Figure 1. Major river networks and valley bottom areas in the Puget Sound Basin, Washington. 
The coarse-resolution assessment summarizes the results of the fine-resolution assessment for floodplain units (FPU) that span laterally across a river valley and longitudinally along a major river segment between tributaries or transitions in valley gradient or confinement. The coarse-resolution assessment also provides metrics for each FPU that indicate the function or risk of the larger floodplain system. All datasets were processed in ArcGIS 10.0 (Environmental Systems Research Institute, 2013) using either grid or shapefile formats. The names of datasets referenced in the text are italicized (for example, land_z_ned) including interim datasets generated and used in processing steps but not included as products with this report

The uncertainty in the assessment outputs depends on uncertainty in source data but also on uncertainty in how multiple factors influence a function or risk and how those factors influence scales over a larger floodplain system. Verification of highly derived outputs that integrate multiple factors over large floodplain systems was outside of the scope of this assessment. Instead, each output is based on a limited number of factors; those factors generally were represented as categories rather than a continuous value to clarify the interpretation of results, and spatial scaling is limited to area-based summation or averaging.

\section{Source Data}

The initial step in the assessment was to compile 20 publically available datasets on topography, geology and soils, hydrography, land cover and land use, water quality, and use of rivers by salmonids listed as threatened or endangered under the Endangered Species Act (table 1). These source data were projected to Universal Transverse Mercator Zone 10 North (UTM Zone 10 N), North American Datum 1983 (NAD 83) coordinate system and clipped to valley bottom areas to reduce the size of the datasets. Source data were used to derive land forms and hydrographic characteristics of floodplains including their connectivity with rivers.

The assessment uses both the $1 / 3$ arc-second National Elevation Dataset (NED) and higher resolution (1.8 m) topography obtained from aerial light detection and ranging (lidar) surveys (table 1). NED was used to delineate valley bottoms, valley gradients, and high floodplains. Lidar data were used to delineate rivers and low floodplains, which would not be well resolved in the NED. Lidar data were available for 74 percent of major river length and 95 percent of the assessment area from the Puget Sound Lidar Consortium (2011). The lidar supermosaic does not cover the western Olympic peninsula, which includes the Big Quilcene, Dosewallips, Duckabush, and Hamma Hamma Rivers, as well as some high-elevation segments of other rivers.

The resolution of the other geospatial sources is variable. Most features (hydrography, roads, levees, railroads, geology, soils, and land use) were based on vector data (point, line, or polygon) where resolution varies with scale ranging from
1:100,000 to $1: 24,000$ (table 1). Raster land-cover source data (C-CAP Regional Land Cover and National Land Cover Data impervious) have a 30-m resolution. Registration of source data after projection to NAD83, UTM Zone $10 \mathrm{~N}$ was not assured and, thus, introduces a source of uncertainty in the assessment. Registration errors would have the greatest effect on attributes along the boundaries of floodplains, on river banks, and on roads. In some cases (for example, a road that occupies a cell with forest land cover), apparent conflicts in attributes of the land surface may be due to registration errors (road data are not aligned with land cover data), limits of data resolution (cell is mostly covered by forest), or physically possible configurations (forest canopy covers the road).

\section{Derived Datasets}

Geospatial datasets with topographic and hydraulic information were derived from the above data sources as intermediate steps in the production of assessment outputs (table 2). The derivative data include extrapolated water-surface elevations, land forms, and floodplain connectivity, which were used throughout the assessment and additional characteristics, such as land-surface and water-surface gradients, and land cover in neighboring cells.

\section{Land Forms-Valley Bottoms, High Floodplains, Low Floodplains, and River Areas}

A modified version of "height above water surface" (Jones, 2006) was used to delineate four land forms - valley bottoms, high floodplains, low floodplains, and river areas. Elevations from the NED for cells crossed by major rivers were extrapolated across each river basin. Areas where the land surface was less than $10 \mathrm{~m}$ above the extrapolated water surface were designated as valley bottoms. The other three land forms (river areas, low floodplains, and high floodplains) were delineated respectively as areas lower than a base water surface elevation plus the estimated changes in stage from median daily stage for a high flow, small flood, and large flood.

The base water surface elevations (riv_z_ned) used to delineate high floodplains were extracted from the elevation values in NED for cells crossed by the NHD flowlines for the major rivers and extrapolated across the valley bottoms using inverse distance weighting. Because of the resolution of NED, cells used to extract river elevations may include river banks and hillslopes. In these cases, river elevations and the extrapolated water surface elevations will have an upward bias. The base water surface elevations used to delineate low floodplain and rivers were extracted from lidar, because of its higher vertical and horizontal resolution, and extrapolated across the valley bottoms. Because lidar data were not available for all river segments, low floodplain and river areas were not delineated comprehensively. 
Table 1. Source datasets used in the geospatial assessment of ecological functions and flood-related risks on floodplains along major rivers, Puget Sound Basin, Washington.

$\left[\mathrm{m}\right.$, meters; $\mathrm{km}^{2}$, square kilometers]

\begin{tabular}{|c|c|c|}
\hline Dataset description & File name & Source \\
\hline $\begin{array}{l}\text { Land surface elevation from National Elevation Dataset, in meters; } \\
10-\mathrm{m} \text { raster }\end{array}$ & land_z_ned & U.S. Geological Survey (2012) \\
\hline $\begin{array}{l}\text { Primary, secondary, local, and private roads; vectors converted to } \\
10 \text {-m raster }\end{array}$ & $v b \_$roads & U.S. Census Bureau (2010) \\
\hline $\begin{array}{l}\text { Major levees and dikes in the Puget Sound basin; polyline vector } \\
\text { converted to } 10-\mathrm{m} \text { raster }\end{array}$ & $v b$ _levees & $\begin{array}{l}\text { U.S. Army Corps of Engineers (2013); Washington State } \\
\text { Department of Ecology (2010); and Roger Fuller } \\
\text { (Western Washington University, written commun., } \\
\text { February 25, 2014) }\end{array}$ \\
\hline Railroads; $1: 24,000$ vector converted to raster & $v b \_r a i l$ & Washington Department of Transportation (2013) \\
\hline $\begin{array}{l}\text { Forested areas indicated by codes } 9-11 \text { and } 13 \text { in the Coastal- } \\
\text { Change Analysis Program (C-CAP) } 2011 \text { Regional Land Cover } \\
\text { Data Set; } 10-\mathrm{m} \text { raster }\end{array}$ & $v b$ forest & $\begin{array}{l}\text { National Oceanic and Atmospheric Administration } \\
\text { (2014) }\end{array}$ \\
\hline $\begin{array}{l}\text { Areas with medium or high development ( }>60 \text { percent impervious } \\
\text { surface) indicated by codes } 2 \text { and } 3 \text { in the C-CAP } 2011 \text { Regional } \\
\text { Land Cover Data Set; } 10-\mathrm{m} \text { raster }\end{array}$ & $v b \_m h d e v$ & $\begin{array}{l}\text { National Oceanic and Atmospheric Administration } \\
\text { (2014) }\end{array}$ \\
\hline $\begin{array}{l}\text { Presence of impervious surface in the } 2011 \text { National Land Cover } \\
\text { Dataset, } 10-\mathrm{m} \text { raster }\end{array}$ & $v b \_$imperv & U.S. Geological Survey (2014) \\
\hline Land use as designated by tax parcel & $v b$ landuses & Washington State Department of Ecology (2010) \\
\hline Erodible surficial geology including unconsolidated sediments, & $v b \_$geoerode & Washington Department of Natural Resources (2010) \\
\hline
\end{tabular}
primary Quaternary alluvium, and glacial/lacustrine deposits; 1:100,000 scale polygons converted to 10 -m raster

Hydric rating of SSURGO soil map units; Soil Survey Geographic Database polygons (variable scale depending on survey) converted to $10-\mathrm{m}$ raster

Volumetric mean fraction silt and clay of SSURGO soil map units; Soil Survey Geographic Database polygons (variable scale depending on survey) converted to 10 -m raster.

Volumetric mean fraction organic matter of SSURGO soil map units; Soil Survey Geographic Database polygons (variable scale depending on survey) converted to $10-\mathrm{m}$ raster

Special Flood Hazard Areas with 1 percent annual probability of flooding; 12:000 scale polygons converted to $10-\mathrm{m}$ raster

Major rivers and their tributaries with greater than $50 \mathrm{~km}^{2}$ drainage area from the high resolution National Hydrography Dataset (file: flowline.shp); 1:24,000 polyline vector

Distributions of Chinook, steelhead, and bull trout from the Salmon ESAfishdist.shp and Steelhead Stock Inventory Assessment Program; 1:24,000 polyline vector

River segments listed as impaired for temperature, dissolved oxygen, or $\mathrm{pH}$ (Clean Water Act Section 303d list); 1:24,000 polyline vector

Class A and B water systems, wastewater treatment facilities, large septic systems, fire stations, hospitals, emergency medical services; points

$v b \_$hydric

$v b \_$siltclay

$v b \_o m$

sfha

PugetRivers.shp

PugetRiversWQ.shp

$v b \_$facilities.shp
Washington State Department of Ecology (2013a)

National Resource Conservation Service (2013)

National Resource Conservation Service (2013)

National Resource Conservation Service (2013)

Federal Emergency Management Agency (2013)

U.S. Geological Survey (2013)

Washington Department of Fish and Wildlife (2013)

Washington Department of Health (2013); Washington State Department of Ecology (2013b) 
Table 2. Derived datasets used in the geospatial assessment of ecological functions and flood-related risks on floodplains along major rivers, Puget Sound Basin, Washington.

$\left[\mathrm{km}^{2}\right.$, square kilometers; m, meters; GIS, geographic information system; NED, National Elevation Dataset $]$

\begin{tabular}{lll}
\hline Dataset description & File & GIS process
\end{tabular}

Water surface elevation ( $\mathrm{m})$ of river from NED riv_z_idw_ned extrapolated across valley bottom

Water surface elevation $(\mathrm{m})$ of river from lidar extrapolated across valley bottom

Valley bottom area where the land surface is less $\quad v b$ than $10 \mathrm{~m}$ above water surface elevation of a river based on NED

Floodplain units representing floodplain areas $\quad f p u . s h p$ associated with river valley segments

Drainage area $\left(\mathrm{km}^{2}\right)$ of the river in the floodplain $f p u \_d r \_$area unit (not the drainage area of a given cell) at the downstream end of the floodplain unit

Nominal stage $(\mathrm{m})$ of a high flow above the water surface of the river

Nominal low flood stage (m) above the water surface of the river

Nominal high flood stage (m) above the water surface of the river

River areas that are likely to include channels and off-channel areas

River areas delineated from lidar or from NHD flow lines

Areas adjacent to but outside of connected river areas representing river banks;

River areas at the edge of the river

Distance (m) to nearest river cell

Low floodplain delineated from lidar

High floodplain delineated from NED

Roads, levees, and railroads

Low floodplain fragments

High floodplain fragments

Floodplain areas categorized by connectivity and $f p$ land form

$r i v \_z i d w \_l i d$

dstage_high

riv_lid

rivmerg

rivmerg_bank

rivmerg_edge

rivmerg_dist

fp_low_lid

frag_lines
Convert major rivers vector (PugetRivers.shp) to raster; create raster of NED elevation of river cells; extrapolate water surface elevation of rivers across valleys using inverse-distance weighting (IDW).

Create grid of river cells from lidar data; create grid of lidar elevation of river cells; extrapolate water surface elevation of rivers across valleys using inverse-distance weighting (IDW).

Calculate the difference between land surface and extrapolated water surface elevations and identify areas less than $10 \mathrm{~m}$ above water surface using $v b=$ land_z_ned $-r i v \_z \_n e d<10 \mathrm{~m}$.

Merge Puget Watershed Characterization analysis units (Washington State Department of Ecology, 2014) to form polygons that spanned laterally across floodplains.

Calculate area of floodplain unit polygons, summed downstream, and added as an attribute of floodplain units; create a raster where the value is the drainage area of floodplain unit.

dstage_riv Calculate stage increase for a high flow, Dstage_riv $=0.5 \times \log 10$ $\left(v b \_d r \_\right.$area $\left./ 10\right)$, to delineate river areas.

dstage low Calculate stage increase for a small flood, Dstage low $=1.3 \times \log 10$ ( $v b \_d r$ area $\left./ 10\right)$, to delineate low floodplain.

Calculate stage increase for a large flood, Dstage_high $=2.0 \times \log 10$ ( $v b \_d r \_$area/10), to delineate high floodplain.

Identify river areas based on the relation, Land_z_lid - riv_z_lid $<$ dstage_riv.

Merge river areas delineated from lidar cells crossed by high resolution NHD flow lines, to represent rivers outside of lidar coverage.

Select cells outside of river area where at least one neighboring cell is in rivmerg.

Select cells in rivermerg where at least one neighboring cell is outside of rivmerg.

Calculate minimum distance to rivmerg.

Identify low floodplain delineated from lidar based on the relation, land_z_lid-riv_z_lid $<$ dstage_low.

$f p \_$high_ned Identify high floodplain delineated from NED based on the relation, land_z_ned -riv_z $<$ dstage_high.

fp_low_frag.shp

Combine roads, levees, and railroads into a single grid, all features have an arbitrary width of one cell $(10 \mathrm{~m})$.

Divide low floodplain into polygons using roads, levees, or railroads, add attribute "Connected" and assign a value of 1 if the polygon is crossed by a river segment or 0 if there is no river segment crossing the polygon.

fp_high_frag.shp Divide high floodplain into polygons using roads, levees, or railroads, add attribute "Connected" and assign a value of 1 if the polygon is crossed by a river segment or 0 if there is no river segment crossing the polygon.

Combine rivmerg, fp_low_frag, fp_high_frag; assign values 3 = river areas $($ rivmerg $=1), 2=$ connected low floodplain $\left(f p \_l o w \_\right.$frag $=$ $1), 1=$ connected high floodplain $\left(f p \_\right.$high frag $\left.=1\right), 0=$ valley bottom outside of floodplain or road/levee/railroad, $-1=$ reduced connectivity floodplain. 
Table 2. Derived datasets used in the geospatial assessment of ecological functions and flood-related risks on floodplains along major rivers, Puget Sound Basin, Washington.-Continued

[km² , square kilometers; m, meters; GIS, geographic information system; NED, National Elevation Dataset]

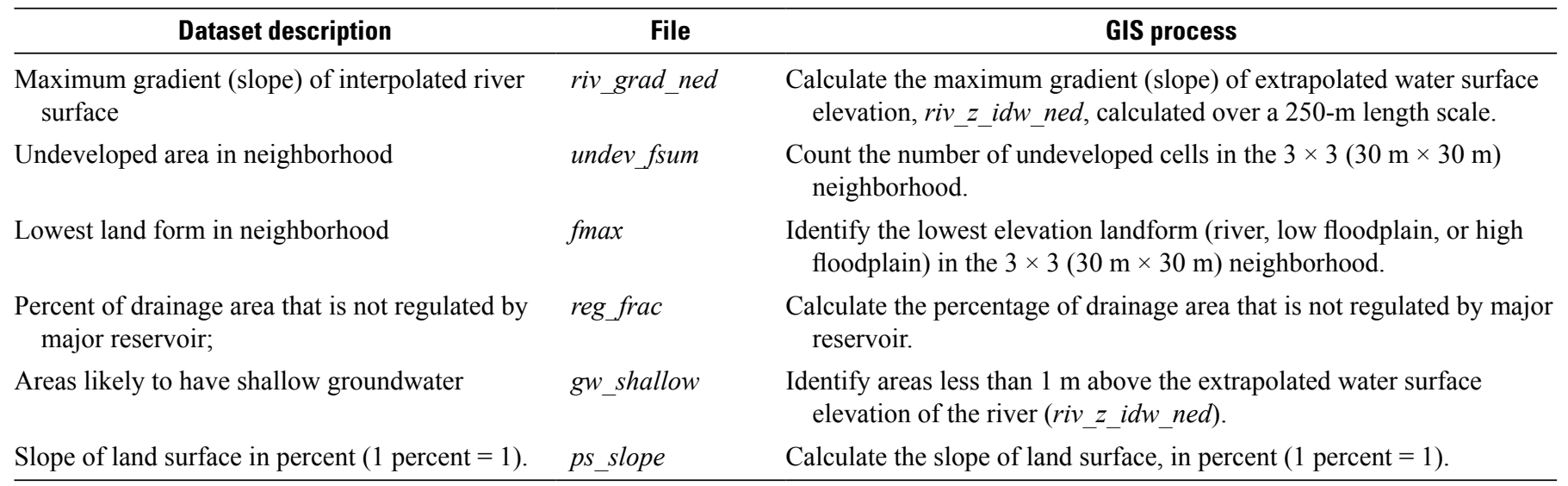

Relations for the increase in stage for a high flow, small flood, and large flood as a function of drainage area were derived from daily stage records from 40 U.S. Geological Survey streamgaging stations on the unregulated river in sections without levees in the Puget Sound Basin with at least 10 years of record. The increase from median daily stage to median annual maximum stage ranged from 0.34 to $3.4 \mathrm{~m}$ depending on the drainage area of the site (fig. 2). The increase from median stage to the 90th percentile of annual maximum stage ranged from 0.5 to $4.2 \mathrm{~m}$. Both of these statistics generally increased with drainage area, so simple relations were derived to estimate the increase in stage (dstage riv, dstage low, and dstage_high) for a high flow event (lower envelope of median annual maximum stage increase), a small flood (upper envelope of median annual maximum stage increase), and a large flood (upper envelope of the 90th percentile of annual maximum stage increase) as a function of the base-10 logarithm $\left(\log _{10}\right)$ of drainage area:

- dstage_riv $=0.5 \log _{10}$ (drainage area/10);

- dstage_low $=1.3 \log _{10}$ (drainage area/10); and

- dstage_high $=2.0 \log _{10}$ (drainage area/10).

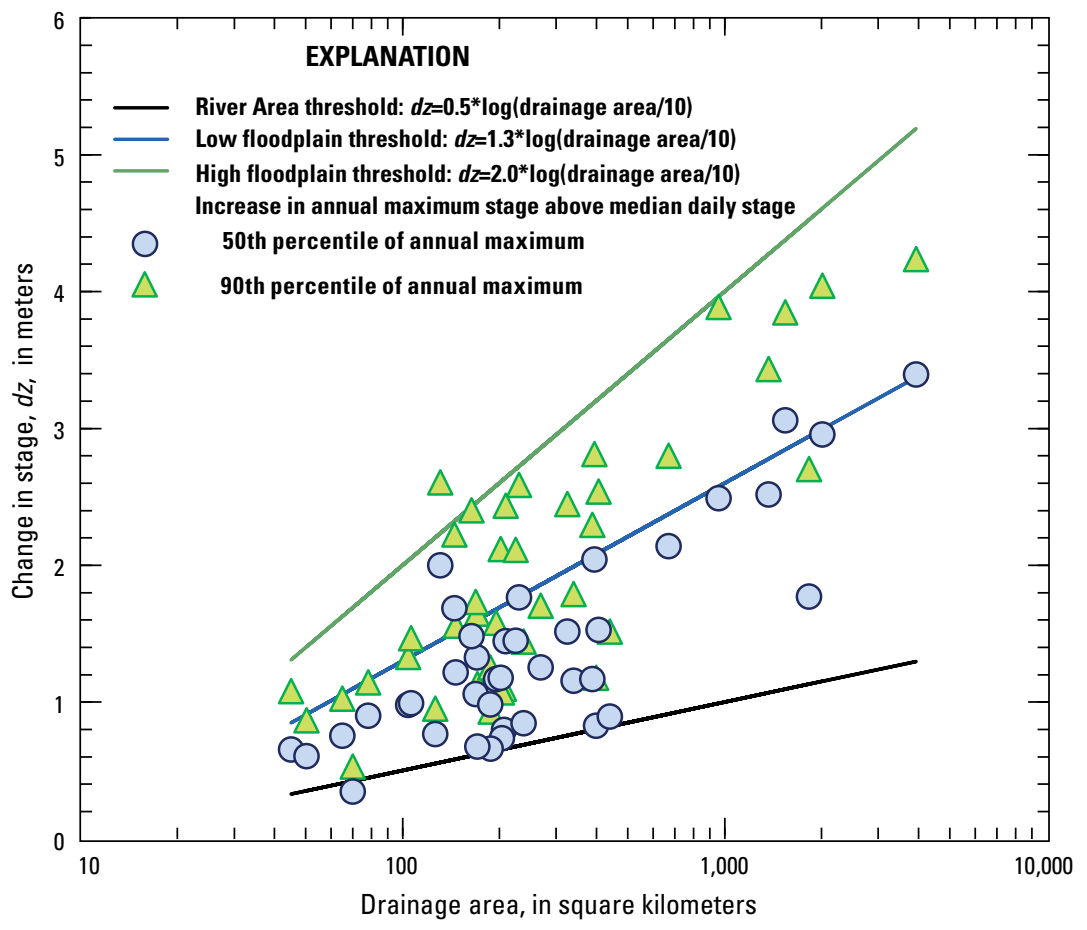

Figure 2. Change in stage from median daily stage for the 50th and 90th percentiles of annual maximum stage as a function of drainage area at 40 U.S. Geological Survey streamgaging stations on unregulated rivers without levees with at least 10 years of daily stage records, Puget Sound Basin, Washington. Lines represent the change in stage used for delineating river areas, low floodplains, and high floodplains. 
The increase in stage for high flows, small floods, and large floods were calculated for each cell in the valley bottom raster based on the drainage area of closest river. Areas where the difference between the land-surface elevation (land_z_lid or land_z_ned depending on the source of elevation data) and interpolated river-surface elevation (riv_z_lid and riv_z_ned) are less than the respective increase in stage for each land form are assigned to that land form:

- river area, land_z_lid - riv_z_lid $<d s t a g e \_r i v$.

- low floodplain, land_z_lid - riv_z_lid $<$ dstage_low; and

- high floodplain, land_z_ned $-r i v \_z \_n e d<d s t a g e \_$ high.

Delineation of floodplains using the elevation of the land surface relative to an estimated water surface elevation based on drainage area was determined to be the best feasible method that could be applied consistently across the Puget Sound Basin. Because the estimated water surface elevations are only approximate, the floodplains delineated from this method have significant caveats. The floodplains do not have specific probability of inundation. Areas higher than high floodplains may be inundated during floods, occupied by rivers, or provide ecological functions associated with floodplains. The floodplains delineated for this assessment should not be used in any application as an alternative to Special Flood Hazard Areas (Federal Emergency Management Agency, 2013).

\section{Connectivity}

The movement of water, biota, sediment, wood, and other materials between rivers and floodplains is a fundamental requirement for many ecological functions of floodplains (Ward and Stanford, 1995; Ward and others, 2002). Floodplains are ecologically disconnected by human actions that limit the frequency, duration, or types of connection between the floodplain and a river even if that floodplain is still inundated during some floods. Flood regulation, bank revetments, levees, and roads disconnect floodplains from rivers by reducing the movement of materials and biota or limiting the movement to a portion of the floodplain. Floodplain connectivity depends on the elevation of the land surface relative to river stage (as discussed for land forms) but also on paths between a floodplain and a river for water, sediment, organic material, and biota, which include small surface distributaries and subsurface zones with high permeability.
Connectivity of floodplains was assessed using topography and infrastructure that are likely to impede the movement of materials or biota. As the first step, any cells crossed by roads, railroads, and levees were removed from the floodplain. This step presumes these features have a nominal width of $10 \mathrm{~m}$ and provide no ecological function. The remaining floodplain cells were converted into polygons where each polygon had a border defined by a road, railroad, levee, or land surface higher than the high floodplain. The resulting floodplain polygons are referred to as "fragments." Fragmentation of floodplains directly from the vector centerlines of roads, railroads, and levees is an alternative, but computationally intensive, approach that nonetheless requires a presumption about the width of these features to close gaps between mapped centerlines where these features actually abut each other.

Any floodplain fragment crossed by a river was designated as a "connected" floodplain. Fragments that were separated from a river by topography, roads, railroads, or levees were designated as a "reduced connectivity" floodplain indicating some type of disconnection is probable. Under this scheme, a floodplain fragment had to be completely surrounded by road, railroad, levee, or high elevation land to have reduced connectivity. Fragments separated from a river by a low road or railroad trestle, for example, would be considered to have reduced connectivity even as some level of connectivity may be maintained through these structures. Conversely, a connected fragment can include areas behind roads or levees that have small gaps even as connectivity would likely be impaired by the road or levee. Further refinement of connectivity requires site-specific information beyond the scope of the assessment.

\section{Fine-Resolution Assessment}

For the fine-resolution assessment, each type of function, hazard, or exposure was assessed in terms of attributes of 10-m cells covering the valley bottoms for all major rivers. Each type of function ( $f n)$, hazard ( $h a z)$, or exposure (exp) has a single primary output file in the fine-scale assessment designated as $f n 1, f n 2, f n 3, f n 4, f n 5, h a z 1, h a z 2, \exp 1, \exp 2$, or exp3. A letter following the primary number (for example, fnla) indicates a secondary output providing additional information about a specific aspect of the function, hazard, or exposure. A summary of the GIS models and output values for all functions, hazards, and exposures are provided in table 3. The output datasets are available online as part of this report. 
Table 3. Summary of models and outputs used for fine-resolution (10-meters) assessment of floodplain function, hazard, and exposure, Puget Sound Basin, Washington.

[ $\mathrm{km}^{2}$, square kilometers; GIS, geographic information system]

\section{Function, Hazard, or Exposure}

\begin{tabular}{|c|c|}
\hline GIS Model & \\
\hline \multicolumn{2}{|l|}{ Output } \\
\hline & Floodplain functions \\
\hline \multicolumn{2}{|c|}{$\begin{array}{l}\text { 1. Store and convey floods } \\
\qquad f n 1=f p * v b \_u n d e v-2 *(f p>0) *\left(1-v b \_m h d e v\right) *\left(1-v b \_u n d e v\right)\end{array}$} \\
\hline \multicolumn{2}{|c|}{ 3: connected, undeveloped river area } \\
\hline \multicolumn{2}{|c|}{ 2: connected, undeveloped low floodplain } \\
\hline \multicolumn{2}{|c|}{ 1: connected, undeveloped high floodplain } \\
\hline \multicolumn{2}{|c|}{ 0: roads, levees, or railroads; not floodplain } \\
\hline \multicolumn{2}{|c|}{-1 : reduced connectivity, undeveloped floodplain } \\
\hline-2 : connect & ess than medium/high) \\
\hline
\end{tabular}

1a. Store floodwater

$f n l a=\left(\right.$ dstage_high $\left.-d z \_n e d\right) *(f p>0)-(f p==-1)$

$>0$ : depth of water during a nominal flood, in meters

0 : roads, levees, or railroads; not floodplain

-1 : reduced connectivity floodplain

1b. Convey floods

$f n 1 b=(f p>1) *\left(v b \_u n d e v\right) *($ riv_grad_ned $)$

$>0$ : hydraulic gradient $[\mathrm{m} / \mathrm{m}]$ based on National Elevation Dataset (U.S. Geological Survey, 2012) for river areas and low floodplains

0 : areas outside of lidar coverage; high or reduced connectivity floodplain; road/levee/railroad; not floodplain

2. Regulate sediment and wood supplies in river networks

$f n 2=v b \_$geoerode $*\left(\left(v b \_\right.\right.$imper $\left.v==0\right) * \operatorname{IsNull}\left(v b \_\right.$fraglines $) *\left(\right.$ rivmerg_bank $*\left(v b \_\right.$forest $\left.+v b \_u n d e v+2-\left(v b \_u n d e v==0\right) * 3\right)+$

$($ rivmerg_bank $==0) *(f p>0) *\left(v b\right.$ forest $\left.+v b \_u n d e v-\left(v b \_u n d e v==0\right) * 2\right)-($ rivmerg_bank $==0) *(f p==-1) *\left(v b \_u n d e v * 3+\right.$

$\left.\left.\left(v b \_u n d e v==0\right) * 4\right)\right)-\left(\left(v b \_\right.\right.$imperv $+\operatorname{IsNull}\left(v b \_\right.$fraglines $\left.\left.)==0\right)>0\right) *$ rivmerg_bank $\left.* 5\right)$

All areas with values other than 0 are composed of unconsolidated material.

4: forest areas adjacent to river with no impervious surfaces

3: undeveloped, non-forested areas adjacent to river with no impervious surfaces

2: forested, connected floodplain with no impervious surfaces

1: undeveloped, non-forested connected floodplain with no impervious surfaces

0 : floodplain on consolidated material; roads, levees, or railroads not adjacent to river areas; not floodplain

-1 : developed areas adjacent to river; no impervious surfaces

-2: developed, connected floodplain; no impervious surfaces

-3: undeveloped reduced connectivity floodplain, no impervious surfaces

-4: developed reduced connectivity floodplain; no impervious surfaces

-5: areas adjacent to river with impervious surfaces, roads, levees, or railroads

2a. Supply sediment

$f n 2 a=r i v m e r g \_b a n k *\left(d z \_n e d\right) *\left(d z \_n e d>0\right) * \operatorname{IsNull}\left(v b \_\right.$frag_lines $) *\left(1-v b \_\right.$imperv $)$

$>0$ : Height $[\mathrm{m}]$ of areas adjacent to river with no impervious surfaces

0: roads, railroads, or levees; river area; areas not adjacent to a river

2b. Retain sediment and particulate organic material

$f n 2 b=(f p>0) * r i v \_g r a d \_n e d * v b \_u n d e v$

$>0$ : hydraulic gradient $(\mathrm{m} / \mathrm{m})$ for undeveloped, connected floodplain

0 : reduced connectivity or developed floodplain; not floodplain 
Table 3. Summary of models and outputs used for fine-resolution (10-meters) assessment of floodplain function, hazard, and exposure, Puget Sound Basin, Washington.-Continued

$\left[\mathrm{km}^{2}\right.$, square kilometers; GIS, geographic information system]

\section{Function, Hazard, or Exposure}

\section{GIS Model}

\section{Output}

Floodplain functions-Continued

3. Retain and transform nutrients and contaminants

$f n 3=\left((f p>0) *\left(v b \_\right.\right.$imperv $\left.\left.==0\right)-(f p==-1)\right) *\left(p s \_\right.$slope $) / 100$

$>0$ : land surface gradient $[\mathrm{m} / \mathrm{m}]$ for connected floodplain with no impervious surface

0 : floodplain with impervious surface; road, railroad, or levee; not floodplain

$<0$ : land surface gradient for reduced connectivity floodplain with no impervious surface

3a. De-nitrification
$f n 3 a=\left(\left(v b \_w e t l a n d+g w \_s h a l l o w+v b \_\right.\right.$hydric $\left.)>0.5\right) *\left(v b \_\right.$imperv $\left.==0\right) *\left(1+\left(v b \_\right.\right.$siltclay $\left.>0.3\right) *\left(\left(v b \_\right.\right.$siltclay $\left.>0.3\right)+$
$\left(v b \_\right.$om $\left.\left.\left.>0.02\right)\right)\right)$
3: valley bottom with anaerobic indicator (wetland, shallow groundwater, or hydric soils), silt/clay $>0.3$, and organic matter $>0.02$, and no impervious surfaces
2: valley bottom with anaerobic indicator; silt/clay $>0.3$, organic matter $<0.02$, and no impervious surfaces
1: valley bottom with anaerobic indicator; silt/clay $<0.3$, organic matter $<0.02$, and no impervious
0: no anaerobic indicator; impervious surfaces

3b. Retain and transform contaminants

$$
f n 3 b=(\text { rivmerg }==0) *\left(v b \_ \text {siltclay }>0.3\right) *\left(v b \_u n d e v\right) *\left(9-v b \_u n d e v f f u m\right)-v b \_ \text {mhdev }
$$

1-8: number of neighboring cells with development (urban, residential, agricultural, or other commercial land use) adjacent to an undeveloped cell on the valley bottom with silt/clay soils; 1 indicates that one of the 8 neighboring cells are developed; 8 indicates that all neighboring cells are developed

0 : none of the neighboring cells are developed; river area

-1 : developed areas of the valley bottom

4. Support forest ecosystems

$f n 4=\left(v b \_\right.$imperv $\left.==0\right) *\left(v b \_u n d e v\right) *((f p>0)-2 *(f p<0))+\left(\left(v b\right.\right.$ forest $+v b \_$wetland $\left.)>0\right)$

2: connected floodplain with forest/wetland cover; no impervious surfaces

1: connected floodplain, undeveloped; no impervious surfaces

0: developed floodplain; impervious surfaces; not floodplain;

-1 : reduced connectivity floodplain with forest/weltand; no impervious surfaces

-2 : reduced connectivity floodplain, undeveloped; no impervious surfaces

5. Provide aquatic habitats

$$
\begin{aligned}
& f n 5=\left(\text { riv } 10 m+\text { riv } 10 m \_e d g e\right) * v b \_u n d e v * \operatorname{IsNull}\left(v b \_ \text {frag_lines }\right) *\left(v b \_ \text {imperv }==0\right) \\
& f n 5 \_m e r g=(\text { rivmerg }+ \text { rivmerg_edge }) * v b \_u n d e v * \operatorname{IsNull}\left(v b \_ \text {frag_lines }\right) *\left(v b \_i m p e r v==0\right)
\end{aligned}
$$

2: undeveloped river edge areas with no roads, railroads, levees, or impervious surfaces

1: undeveloped river areas with no roads, railroads, levees, or no impervious surfaces

0 : areas above river stage; developed areas; areas with road, railroads, or levees, impervious surfaces

\section{Flood-related hazards}

\section{Inundation}

$h a z 1=s f h a * f p-2 *(s f h a==0) *(f p \neq 0)$

3: connected river areas in special flood hazard area (SFHA)

2: connected low floodplain in SFHA (areas likely to be inundated during floods)

1: connected high floodplain in SFHA (areas that may be inundated during major floods)

0 : neither SFHA nor floodplain

-1 : reduced connectivity floodplain in SFHA (areas dependent on infrastructure to reduce flooding)

-2: floodplain out of SFHA (areas that may depend on infrastructure to prevent floods) 
Table 3. Summary of models and outputs used for fine-resolution (10-meters) assessment of floodplain function, hazard, and exposure, Puget Sound Basin, Washington.-Continued

[km², square kilometers; GIS, geographic information system]

\section{Function, Hazard, or Exposure}

\section{GIS Model}

\section{Output}

Flood-related hazards-Continued

\section{Channel occupation}

$h a z 2=v b \_g e o e r o d e *(f p \neq 0) *\left(1+\left(\right.\right.$ rivmerg_dist $\left.<\left(10 * \operatorname{SquareRoot}\left(f p u \_d r \_a r e a\right)\right)\right) *\left(1+\left(\right.\right.$ rivmerg_dist $\left.<\operatorname{SquareRoot}\left(f p u \_d r \_a r e a\right)\right)$ $+3 *($ fpu_grad $>0.002)+3 *\left(f p u \_g r a d>0.005\right)+\left(\left(\operatorname{slp} 30 d S Q K M / f p u \_\overline{d r}\right.\right.$ area $\left.)>0.2\right) *\left(f p u \_g r a d>0.002\right) *($ rivmerg_dist $<$ SquareRoot $\left(f p u \_d r \_\right.$area $\left.\left.)\right)\right)$)

10: erodible areas close to high gradient rivers with high sediment loads

9: erodible areas close to high gradient rivers with moderate sediment loads

8: erodible areas near to high gradient rivers

7: erodible areas close to intermediate gradient rivers with high sediment loads

6: erodible areas close to intermediate gradient rivers with moderate sediment loads

5: erodible areas near to intermediate gradient rivers

3: erodible areas close to low gradient rivers

2: erodible areas near to low gradient rivers

1: erodible areas on floodplain faraway from rivers

0: floodplains on consolidated geology; roads, railroads, or levees

Proximity scales with drainage area. The distance from a "close" areas to a river is less than square root of drainage area of the associated river (within $10 \mathrm{~m}$ of a river with a $100 \mathrm{~km}^{2}$ drainage area, $100 \mathrm{~m}$ for a river with $10,000 \mathrm{~km}^{2}$ drainage area). The distance from a "near" areas to a river is greater than the square root of drainage area of the associated river but less than 10 times the square root of drainage area of the associated river (between 10 and $100 \mathrm{~m}$ for a river with a $100 \mathrm{~km}^{2}$ drainage area and between 100 and $1,000 \mathrm{~m}$ for a river with a $10,000 \mathrm{~km}^{2}$ drainage area).

Sediment loads are considered high if more than 20 percent of a river's drainage area is unregulated with slopes greater than 30 degrees.

River gradients greater than 0.005 are steep, 0.002 to 0.005 are intermediate, and less than 0.002 are low.

2a. Bank erosion

$h a z 2 a=v b \_g e o e r o d e *$ rivmerg_bank $*\left(v b \_s i l t c l a y<0.3\right) *\left(f p u \_s i n u o u s>11\right) *\left(1+\left(f p u \_s i n u o u s>14\right)+2 *\left(f p u \_g r a d>0.002\right)+2 *\right.$ (fpu_grad $>0.005))$

6: erodible banks along a steep, meandering river

5: erodible banks along a steep, sinuous river

4: erodible banks along an intermediate gradient, meandering river

3: erodible banks along an intermediate gradient, sinuous river

2: erodible banks along a low gradient, meandering river

1: erodible banks along a low gradient, sinuous river

0 : not river bank or river bank formed from consolidated geologic material

Meandering rivers have a sinuosity $>1.5$, sinuous rivers have a sinuosity from 1.2 to 1.5 .

2b. Avulsion

$h a z 2 b=(f p>1) *(1+($ riv_grad_ned $>0.002)+($ riv_grad_ned $>0.005)) *\left(1+2 *\left(\left(\operatorname{slp} 30 d S Q K M / f p u \_d r \_a r e a\right)>0.2\right)\right)$

5: river and low floodplain areas along high gradient rivers with high sediment loads

4: river and low floodplain areas along high gradient rivers with moderate sediment loads

3: river and low floodplain areas along intermediate gradient rivers with high sediment loads

2: river and low floodplain areas along intermediate gradient rivers with moderate sediment loads

1: river and low floodplain areas along low gradient rivers

0: high floodplain; road, railroad, or levee; or not floodplain 
Table 3. Summary of models and outputs used for fine-resolution (10-meters) assessment of floodplain function, hazard, and exposure, Puget Sound Basin, Washington.-Continued

$\left[\mathrm{km}^{2}\right.$, square kilometers; GIS, geographic information system]

\section{Function, Hazard, or Exposure}

\begin{tabular}{c}
\hline GIS Model \\
\hline Output \\
\hline
\end{tabular}

1. Key facilities

$$
\begin{aligned}
& \exp 1=v b \_ \text {facilities } *\left(10^{*}(f p>10)+(f p==1)-(f p==-1)\right) \\
& 0: \text { no key facility }
\end{aligned}
$$

$10,1,-1$ : water system on low floodplain, high floodplain, and reduced connectivity floodplain, respectively

20, 2, -2: wastewater discharge on low floodplain, high floodplain, and reduced connectivity floodplain, respectively

30, 3, -3: large septic system on low floodplain, high floodplain, and reduced connectivity floodplain, respectively

40, 4, -4: fire station on low floodplain, high floodplain, and reduced connectivity floodplain, respectively

$50,5,-5$ : hospital on low floodplain, high floodplain, and reduced connectivity floodplain, respectively

$60,6,-6$ : emergency medical service facility on low floodplain, high floodplain, and reduced connectivity floodplain, respectively

2. Land uses

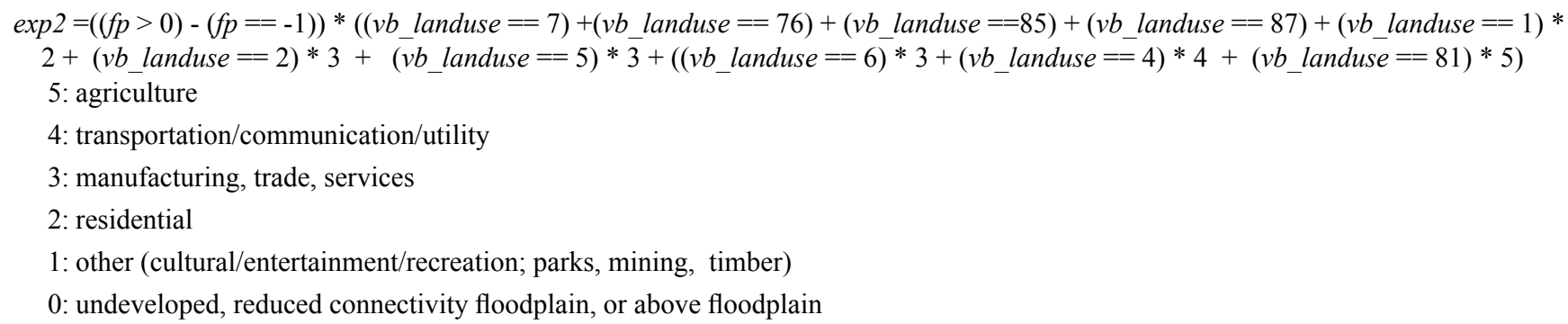

3. Roads

exp3 $=f p \_$focmax, $v b \_r o a d s$ as mask

3: road that border river area

2: road that border connected low floodplain

1: road that border connected high floodplain

0: not road; road not adjacent to river or floodplain

The outputs from the fine-resolution assessment generally are categories of function or risk where each category represents a unique combination of attributes (for example, connected floodplain with impervious surface). Each output category is intended to represent functionally distinct types of floodplains, but the value assigned to the category does not represent the degree of function. In some cases, areas with the highest value may be expected to provide the most function and areas with the lowest value may be expected to provide the least function. This convention does not hold in many cases, so the degree of function should not be presumed from the order of output values. For example, the output values for a disconnected floodplain with forest cover and a connected floodplain with development are not intended to indicate whether disconnection or land cover conversion has a greater influence on a function. The values are only intended to indicate that these floodplains likely have functional differences. Zero values are reserved for areas where the function, hazard, or exposure is unlikely because of either biophysical or social factors. Negative values are reserved for areas that may not provide a function but may have potential for improvement (for example, reduced connectivity floodplain with forest cover) or that represent a distinct class (for example, reduced connectivity floodplain) where the output is a continuous variable.

\section{Floodplain Functions}

\section{Function 1. Store and Convey Floods}

The defining characteristic of floodplains is their capacity to store and convey water during floods. This function depends on areas that have a lower elevation than flood stage and are connected to a river. In addition, floodplains that convey floodwater must be relatively free of obstructions that impede 
flowing water. The six output categories for this function represent combinations of the relative elevation of floodplain areas (low or high floodplain), connectivity (connected and reduced connectivity), and level of development, which may indicate the presence of structures that could interfere with this function. Floodplains with roads, levees, railroads, or medium/ high levels of development are assigned an output value of 0 because they are not anticipated to store or convey significant volumes of water during floods and generally are not managed to provide this function during floods.

Key assumptions/uncertainties. - The delineation of floodplains in this assessment produces coarse boundaries and resulting floodplains have neither a specific nor uniform probability of inundation. The floodplains are likely to include most areas inundated during frequent floods and some areas that are inundated infrequently. Roads, railroads, and levees are assumed to disconnect floodplain areas from rivers only when they form a continuous boundary around floodplain areas. In some cases, floodplains may have reduced connectivity even if roads, levees, and railroads do not form a continuous boundary around them. Conversely, road, railroads, and levees may not be effective barriers to inundation during some floods.

\section{Function 1a. Store Floodwater}

Floodplains store water during floods, which maintain soil moisture, groundwater recharge, and temporary aquatic habitats (Ward and others, 2002). The storage volume provided by a floodplain area depends on the elevation of the land surface relative to flood stage. The difference between the land-surface elevation and flood stage can be used as an approximate index of the storage capacity of a floodplain. The output for this function is the depth of water (continuous values with units of meters) at a given location for a nominally high flood stage. Reduced connectivity floodplains are assigned a value of -1 . Floodplains with roads, levees, or railroads are assigned an output value of 0 for this function.

Key assumptions/Uncertainties. - The change in stage expected for a high flood is based on the relation between the changes in stage for the 90th percentile flood at streamgaging stations in reaches without levees. Streamgaging stations typically are located in more confined reaches, so the change in stage at these locations would have an upward bias compared to reaches in unconfined floodplains. All roads, levees, and railroads are treated as barriers to flooding without discriminating at what river stage they actually provide a barrier to flooding. This methodology does not represent local variation in flood discharge and stage and should not be considered an estimate of flood depth at any location.

\section{Function 1b. Convey Floods}

Floodplains convey water during floods, which reduces the spatial extent and depth of flood inundation in surrounding areas (Konrad and others, 2008). The capacity of floodplains to convey floods depends primarily on their width, hydraulic gradient, which can be approximated by the water-surface gradient and roughness (Chow, 1959). In most floods, only the river channel and low adjacent floodplains convey water, so the assessment of this function is limited to connected low floodplain and river areas. Roughness is a measure of flow resistance and comes from various sources including meander bends, gravel bars, vegetation, debris, and the surface material of a river channel or floodplain (Knighton, 1998). Most of the major rivers in the Puget Sound Basin are wider than $10 \mathrm{~m}$, so width is addressed in the coarse-resolution assessment. The output values for this function are hydraulic gradient (continuous values with units of meters per meter) for connected river and low floodplain that are likely to have low flow resistance. Areas outside of lidar coverage, reduced connectivity floodplains, floodplains with low to high development, forests, roads, levees, or railroads are assigned an output value of 0 for this function.

Key assumptions/Uncertainties. - River areas and low floodplains are more important than high floodplains for conveying floods. River areas were delineated only where lidar data were available. River gradients calculated from the interpolated river surfaces over a length of $250 \mathrm{~m}$ may not represent hydraulic gradients of rivers at flood stage, such as where local channel morphology or debris forms constrictions. In reaches with uniform widths and flow resistance, however, hydraulic gradients can be expected to become more uniform at increasing stage. Forests and developed areas may convey floodwaters, but are assumed to contribute substantially less conveyance capacity than other areas. Areas likely to have low flow resistance include open space, cultivated land, pasture, grassland, scrub/shrub including wetland, bare land, and water (C-CAP codes 5, 6, 7, 8, 12, 14, 15, 17, 18, 19, 20, and 21). Areas with low to high development or forest of any kind (codes 2, 3, 4, 9, 10,11,12,13, and 16) are likely to have higher flow resistance.

\section{Function 2. Regulate Sediment and Wood Supplies in River Networks}

Floodplains regulate fluvial transport of sediment and large woody debris delivered from headwater streams and hillslopes through river networks (Fetherston and others, 1995; Knighton, 1998). These materials are deposited on floodplains, contributing to the formation of aquatic and terrestrial habitats, and may be eroded later, serving as a proximate supply of these materials to downstream reaches. The capability of areas to store and supply sediment to river networks during floods depends on their accessibility by a river, land cover, and surficial geology. The 10 output categories for this function incorporate forest cover, erodible materials, proximity to rivers, and connectivity. Areas that are on consolidated materials (bedrock) and roads, railroads, or levees are assigned an output value of 0 for this function. 
Key assumptions/Uncertainties. - River banks and floodplains are proximate source of sediments for fluvial transport. Hillslopes above floodplains are a source of sediment addressed under Function 2a. Unconsolidated materials (for example, sand, gravel) are much more erodible than bedrock, other consolidated material, and clay. Areas with impervious surfaces, road, levees, and railroads are likely to be protected by revetments to protect the infrastructure and generally do not supply sediment or wood to channels. Developed areas can include some trees, but the supply of large woody debris would be limited from these areas. River areas were delineated only where lidar data were available. Forest cover classes do not distinguish age, size, or density of trees, which influence the value of the forest for contributing large woody debris to a river network. Conifer, deciduous, and mixed forest types were considered equivalent for supplying wood.

\section{Function 2a. Supply Sediment}

Floodplains and hillslopes along river channels are the local supply of sediment to rivers (Knighton, 1998). Although river banks supply sediment to rivers when they are eroded during high flows, steep, high hillslopes deliver sediment to rivers and floodplains through landslides and other forms of mass wasting. Revetments often are used to protect roads, railroads, levees, and other infrastructure in close proximity to rivers by preventing erosion. The output values for this function are the height of areas adjacent to rivers (continuous value with units of meters) without roads, levees, railroads, or other impervious surface. Floodplain areas that are not adjacent (neighboring cell) to rivers are assigned an output value of 0 for this function.

Key assumptions/Uncertainties.-Margin height indicates the potential volume of sediment delivered to a channel through bank erosion. Consolidated materials including bedrock can be an important source of sediment where those materials form high bluffs adjacent to rivers. The erodibility of material is not considered in this assessment but does influence the sediment supply rate to rivers. River margins were delineated only where lidar data where available. River margins areas with infrastructure likely do not supply sediment because of revetments.

\section{Function 2b. Retain Sediment and Particulate Organic Material}

Floods can deposit sediment, wood, and other particulates on floodplains in areas where flow velocities are low enough to allow deposition. The hydraulic gradient of the river indicates the velocity of water and its competence to transport sediment and other particulates. Floodplains with reduced connectivity may not be inundated as frequently and, thus, will not receive sediment and organic material inputs. The output values are the hydraulic gradient of the river in undeveloped areas of connected floodplains. Reduced connectivity or developed floodplains are assigned an output value of 0 for this function.

Key assumptions/Uncertainties.-Floodplains along low gradient rivers are more likely to retain particulate materials than those along high gradient rivers. Retention time is inversely related to hydraulic gradient. The retention of sediment is only assessed for undeveloped floodplains, although agricultural lands or developed open space also may retain sediment during floods.

\section{Function 3. Retain and Transform Nutrients and Contaminants}

Floodplains retain dissolved materials, including nutrients and contaminants that constitute water pollutants, where water is stored on floodplains and sorbed to soil particles (Marcus, 1989; Baldwin and Mitchell, 2000; Pinay and others, 2002). Transformations depend on biophysical conditions (light, reduction-oxidation potential, availability of co-reactants/microbes, $\mathrm{pH}$, etc.) specific to each constituent, but generally lower gradient floodplain areas will have longer retention times and fine-grained soils that promote retention and biogeochemical transformations (Smith and others, 1988; Pinay and others, 2000). Areas with impervious surfaces are unlikely to retain water pollutants because of limited contact between floodwaters and soil. The output values for this function are land surface gradient for connected floodplain with no roads, levees, railroads, or other impervious surfaces, and land surface gradient for reduced connectivity floodplain with no roads, levees, railroads, or other impervious surfaces.

Key assumptions/Uncertainties. - Low gradient floodplains that are inundated frequently are most effective at retaining pollutants. Soil data generalize river areas as coarsegrained alluvium without distinguishing sand and finer grained facies along rivers, so land surface gradient may be a more reliable indicator of fine-grained material in river areas where soils are mapped as alluvium. Although floodplains retain nutrients and contaminants sorbed to fine sediments, these pollutants can be resuspended during subsequent flooding.

\section{Function 3a. Denitrification}

Floodplains can act as zones of denitrification where soil microbes transform nitrate into molecular nitrogen under anaerobic conditions (Pucket and others, 2008; Tesoriero and Puckett, 2011). Organic carbon serves as the electron donor and nitrate as the electron acceptor in denitrification. Nitrate is only formed under aerobic condition, so denitrification can only occur where there is spatial or temporal transition from aerobic to anaerobic conditions in the soil column (Baldwin and Mitchell, 2000). Denitrification is associated with high silt and clay content, which was greater than 65 percent for areas of denitrification on one floodplain (Pinay and others, 2000). This function is assessed in terms of the primary three 
denitrifying conditions (anaerobic soils, fine-grained sediment, and organic carbon) where the likelihood of denitrification is highest in the presence of all three conditions.

Key assumptions/Uncertainties. - Nutrient sources are not assessed, but are assumed to be uniformly available across the valley bottom. Retention time, contact with soil, and the juxtaposition/ transition from anaerobic and aerobic environments are the primary factors limiting denitrification in river floodplains. Wetlands, shallow groundwater, or hydric soils indicate the likelihood for anaerobic conditions, but not the transitions between aerobic and anaerobic conditions. Fine-grained substrate provides the necessary surface area and retention time for denitrification. Despite a mechanistic understanding of denitrification, the key factors may not account for field measurements of floodplain denitrification (Orr and others, 2007). As a result, denitrification is highly uncertain even in areas classified as most likely to support this function.

\section{Function 3b. Retain and Transform Contaminants}

Floodplains may be able to retain and transform some contaminants (Marcus, 1989). This capacity depends on sources of contaminants in proximity to floodplains areas with long retention times (weeks) and soils that will sorb the contaminants (Smith and others, 1988), which will promote retention or transformation, or both. Potential sources of contaminants in this assessment include urban, agricultural, and residential land uses. Contaminants are transformed through aerobic and anaerobic processes, so no distinction is made for this function based on floodplain elevation. The output values for this function are the number of neighboring cells (0-8) with development (sources of contaminants) for each undeveloped cell with high silt/clay. Floodplain areas with development are assigned an output value of -1 to represent potential sources of contaminants.

Key assumptions/Uncertainties. - Fine-grained soil provides sufficient surface area and contact time for transformations, whereas coarse-grained soils do not. River areas are likely to transport contaminants rather than retain and transform them, although some contaminants may deposit with fine-grained sediments in low velocity river areas. Developed areas are unlikely to retain or transform contaminants except where stormwater controls are in place. In these cases, however, retention is not solely a function of floodplains. Transformation of contaminants is highly uncertain even in areas most likely to support this function.

\section{Function 4. Support Forest Ecosystems}

Floodplains support productive and diverse forest ecosystems in areas where trees can grow to maturity, rivers deposit sediment that can be colonized by early seral stage plants, and where they are not fragmented by human development (Naiman and others, 2010). The five output categories for this function represent combinations of connectivity and forest/wetland cover. Areas with impervious surfaces or other development including agriculture are assigned an output value of 0 for this function.

Key assumptions/Uncertainties. - Dominant vegetation type (for example, trees, shrubs, grass) is the primary factor in determining whether floodplains support forest ecosystems. Undeveloped areas without forest or wetland cover have the potential to support forests. Other factors, such as soils, trees species and age structure, canopy heights and openings, and patch size, are not considered. Floodplain forests need to be connected to rivers to be fully functional, but forests on floodplains with reduced connectivity can support some functions.

\section{Function 5. Provide Aquatic Habitats}

Floodplains provide a variety of aquatic habitats with distinct hydroperiods, depths, velocities, and substrates (Ward and others, 2002). Among these, shallow, low velocity water along the edges of river-channel and off-channel areas is a preferred habitat for rearing of juvenile salmonids (Beechie and others, 2005). The two output categories indicating this function are undeveloped river edges and undeveloped river areas. River areas with roads, levees, railroads, or other development and floodplain areas above rivers are assigned an output value of 0 for this function.

Key assumptions/Uncertainties. - In areas without lidar coverage, river areas were defined as cells crossed by river segments from the National Hydrography Dataset (NHD) high resolution hydrography. In these areas, river areas are only one cell wide and, as each river cell as non-river neighbors, all river cells are designated as edge. Land-cover data have a 30-m resolution and, thus, should only be considered a coarse indicator of land cover in the vicinity of river edges.

\section{Flood-Related Hazards}

\section{Hazard 1. Inundation}

Inundation of land area during floods represents a hazard to people using floodplains. Areas with an annual probability of inundation greater than 0.01 are designated as Special Flood Hazard Areas (Federal Emergency Management Agency, 2013). Within SFHA, the probability of flooding is likely to depend on the elevation of the land surface and connectivity with rivers, so the output for this hazard defines four categories of SFHA corresponding to river areas, low floodplain, high floodplain, and reduced connectivity floodplain. Inundation hazard with an annual probability less than 0.01 may be present outside of SFHA in higher elevation areas of the floodplain or in areas protected by infrastructure. Such areas are a fifth output category. Areas outside of the SFHA and floodplain are assigned an output value of 0 for this hazard. 
Key assumptions/Uncertainties.-The distinction of inundation hazard within SFHA is only approximate. Hydraulic modeling incorporating site-specific information would be needed to estimate the probability of inundation of floodplain areas. River and low floodplain areas have not been delineated in areas without lidar coverage. Because of the methods used for delineating floodplain, floodplain areas outside of SFHA may have a low inundation hazard.

\section{Hazard 2. Channel Occupation}

Rivers change their position on floodplains as a result of progressive bank erosion and deposition or a rapid shift of flow (or avulsion) to a new location. The shifting occupation of floodplains by rivers represents a hazard to many uses of floodplains and, as a result, this hazard has been traditionally managed by using revetments or other structures to prevent bank erosion or to block off floodplain areas that are not currently occupied by a river. The degree of this hazard at a given location on a floodplain depends on the frequency and distance of expected channel movement, which depend on the type and elevation of floodplain materials, stream power available to transport sediment, and sediment load (Hickin and Nanson, 1984; Nanson and Croke, 1992; Kleinhans and others, 2012; Konrad, 2012).

Among mountain rivers in the Puget Sound Basin, the probability that the river will occupy a floodplain area is associated with the river's plan form, ranging from floodplains with straight channels (lowest probability) to floodplains with braided channels (highest probability), which primarily reflects increasing slope and, to a lesser extent, decreasing streamflow (Beechie and others, 2006). Likewise, in the Puget lowland, channel migration rates and occupation of floodplains by rivers exhibit a strong contrast between low-gradient $(<0.001)$ valleys where rivers have been depositing sediments in the Holocene (low migration rates) to steeper $(>0.001)$ valleys where rivers have been eroding and reworking valley bottom sediments in the Holocene (Collins and Montgomery, 2011). As a result, river gradient is a primary factor used to assess channel occupation hazard on a floodplain.

Sediment load is the second factor that is incorporated into the assessment of channel occupation hazard. Generally, rivers with high sediment loads are more dynamic, shifting their location in response to deposition of sediments along their channel. Sediment load is indexed in terms of the fraction of the river's basin that is unregulated with slopes greater than 30 degrees. White River is considered unregulated with regard to sediment load because Mud Mountain Dam passes coarse sediment.

Observed migration rates generally increase with stream power (maximum rate of work possible from a river), which is the product of gradient, streamflow, and the specific weight of water (Hooke, 1980; Nanson and Hickin, 1986; Konrad, 2012). To account for variation in stream power related to streamflow, drainage area is incorporated as a third factor to assess this hazard.
A river is more likely to re-occupy locations that it recently occupied (Konrad, 2012), which are generally located close to the current channel position (Beechie and others, 2006, fig. 8; Collins and Montgomery, 2011, fig. 9) partly because channel occupation is a consequence of lateral migration and widening during floods (Konrad and others, 2011). To account for the decreasing probability of occupation with distance to a river, distance to a river is used as a fourth factor to assess this hazard. These factors are combined into 10 categories representing combinations of river gradient, sediment load, and distance to a river scaled by the drainage area of the river.

Key assumptions/Uncertainties. - Steep rivers are more dynamic across different types and within types. Sediment loads are a primary factor contributing to instability, but are not incorporated in this hazard. Areas close to rivers have a greater probability of channel occupation than areas farther away from the river's current location, but proximity to a river will change over time. Revetments intended to protect roads, levees, railroads, and other structures may provide some protection against, but do not eliminate, the possibility of channel occupation.

\section{Hazard 2a. Bank Erosion}

Bank erosion represents a hazard to land use on floodplains adjacent to rivers. Bank erosion rates are related to many of the same factors as channel occupation, although stream power, proximity to a river, bank materials and vegetation, bank height, and the curvature of river bends are among the most significant ones (Knighton, 1998). As a subcategory of channel occupation, bank erosion hazard is only evaluated for river bank areas, so the assessment focuses on factors related to incidence of bank erosion rather than its rate (for example, stream power). Bank erosion is most likely for non-cohesive bank material along river segments with meander bends. Soils with less than 30 percent silt and clay are considered non-cohesive. The assessment of this hazard uses sinuosity, which is river path length divided by straight-line distance and river gradient to produce six output categories. Areas that are not river bank and river bank areas formed from consolidated geological materials or cohesive sediments are assigned an output value of 0 for this hazard.

Key assumptions/Uncertainties.-Bank erosion hazard will change as a river shifts locations on a floodplain. Erosion is treated as equally probable along either side of the river ignoring local features that affect bank erosion hazard, such as meander bends and bluffs. Bank erosion generally is more prevalent along the outer banks of meander bends. Straight segments have some level of bank erosion hazard, but it is not addressed in this assessment. Cohesive strength of banks increases with silt and clay content (Knighton, 1998). Cohesive sediments resist erosion but do not eliminate bank erosion hazard. Engineered revetments have not been incorporated into this hazard because of the lack of consistent and comprehensive mapping. 


\section{Hazard 2b. Avulsion}

Rivers can rapidly shift location, or avulse, when their channel becomes blocked by sediment and debris or if high flows erode through an obstruction to a flow path that is lower than their channel (Slingerland and Smith, 2004; Kleinhans and others, 2012). Deposition of sediment and debris in reaches where sediment transport capacity decreases downstream (for example, transition from a steep, narrow valley to a less steep, wider valley, such as where an alluvial fan would be expected to form) commonly initiate avulsions. Avulsions also can occur when debris or meander bends create high flow resistance, backing up water that can access an alternative, steeper flow path across the bend or into a former channel that is at a lower elevation. Evidence for avulsion hazard includes abandoned channels, large in-channel deposits of sediment, and an anabranching (multiple channels and islands) plan form. Although anabranching rivers indicate past avulsion, a high gradient river with high sediment and debris loads in unconfined reaches generally can be expected to avulse with higher frequency than other types of anabranching rivers (Nanson and Knighton, 1996; Kleinhans and others, 2012).

Generally, high gradient rivers with high sediment can be expected to avulse more frequently than low gradient rivers with moderate sediment loads notwithstanding local factors that contribute to sediment deposition and affect flow direction. Avulsion hazard is assessed for low-lying areas along rivers in terms of five categories representing combinations of river gradient and sediment load. High floodplain areas are assigned an output value of 0 for this hazard, although avulsion hazard may be present in some of these areas.

Key assumptions/Uncertainties. - Hydraulic gradient is a primary driver of sediment transport and deposition that drive channel avulsion (Kleinhas and others, 2012) and accounts for anabranching channel forms of major rivers in the Puget Sound Basin. Additional factors contributing to avulsion hazard include large woody debris, local divergence of hydraulic gradient (concavity of the river profile), and geomorphic features, such as alluvial fans, abandoned channels, and meander bends, none of which are included in the assessment of this hazard.

\section{Flood-Related Exposures}

\section{Exposure 1. Key Facilities}

Flooding poses a risk to many facilities located on floodplain including those that provide vital services. Disruption in water supplies, wastewater treatment, and emergency services could be critical issues during floods, so exposure of key facilities providing these services is an important component of flood-related risks to people in the Puget Sound Basin. This type of exposure is assessed by assigning a value indicating the type of facility to each cell where there is a key facility on a floodplain. All other cells are assigned an output value of 0 for the exposure of key facilities.

Key assumptions/Uncertainties. - Facilities are based on point source data. The actual footprints of these facilities likely extend beyond the 10-m cell assigned to represent the facility in the output for this type of exposure. The probability of flood-related hazards for these facilities and their vulnerability are important considerations in assessing risk but are beyond the scope of this assessment.

\section{Exposure 2. Land Uses}

People using floodplains are exposed to flood-related hazards. The level of exposure of different land uses to flood-related hazards varies across the Puget Sound region reflecting regional patterns in land use. The output values for the assessment of this type of exposure are codes indicating the general type of land use on the floodplain. Exposure of five types of land uses is assessed - agriculture; transportation/ communication/utility; manufacturing, trade, services; residential; and other (cultural/entertainment/recreation; parks, mining, timber).

Key assumptions/Uncertainties. - Exposure is treated as uniform within each of the use categories. The location of infrastructure and uses of land within parcels will determine the actual exposure to flood-related hazards.

\section{Exposure 3. Roads}

Floodplains are commonly used as transportation corridors. Roads exposed to flooding represent a significant risk in the Puget Sound Basin. The exposure of roads depends on the connectivity and elevation of floodplain areas adjacent to the road. This type of exposure to flooding is assessed in terms of the lowest land form (river, low floodplain, high floodplain) in the 8-cell neighborhood of any cell with a road.

Key assumptions/Uncertainties. - Road areas were based on vector representations of centerlines rather than edges. When the roads were gridded, they assume a width of 1 cell $(10 \mathrm{~m})$. This likely underestimates the actual location of road areas and their exposure to flood-related hazards. River areas and low floodplain are mapped only in areas with lidar coverage.

\section{Coarse-Resolution Assessment}

The coarse-resolution assessment summarizes the results of the fine-resolution assessment for larger floodplain systems and accounts for factors influencing function and risk at larger scales than could be addressed in the fineresolution assessment. Function and risk were assessed for each of 535 FPUs along major rivers in the Puget Sound Basin. FPU boundaries are based on Puget Watershed Characterization (PWC) analysis units (Washington State 
Department of Ecology, 2013a), which were defined by tributary junctions, river gradient, and valley confinement and generally are consistent with the river segments used in the Salmon and Steelhead Habitat Inventory Program (Washington Department of Fish and Wildlife, 2013). In cases where PWC analysis units did not extend laterally across a valley bottom, they were combined into a single FPU. FPUs range from 5 to 15,700 ha in area and encompass segments of rivers up to $21 \mathrm{~km}$ in length (median segment length of $5.7 \mathrm{~km}$ ). They generally increase in area and length from headwater areas where floodplains are confined in narrow valleys to wide river deltas where floodplains may be many kilometers wide.

The coarse-resolution assessment provides additional FPU-scale attributes and indices that are relevant for assessing ecological function and risk. Attributes are measureable features, such as floodplain area, hydraulic gradient of the river, sinuosity, or upstream regulation (table 4). Indices of floodplain function or risk (table 5) are derived to provide standardized measures that can be compared among FPUs or to integrate multiple factors influencing a function.

Table 4. Attributes of floodplain units used in the geospatial assessment of ecological functions and flood-related risks on floodplains along major rivers, Puget Sound Basin, Washington.

[m, meters; $\mathrm{km}^{2}$, square kilometers]

\section{Attribute [units]}

Floodplain unit (FPU) identification number

Drainage area at downstream end of floodplain unit [SQ KM]

Length of mainstem river segments in floodplain unit $[\mathrm{KM}]^{1}$

Water surface gradient $[\mathrm{M} / \mathrm{M}]^{2}$

Downstream change in water surface gradient $[\mathrm{M} / \mathrm{M}]^{2}$

Ratio of river length to valley length [M/M]

Fraction of drainage area that is unregulated (no large reservoirs)

Fraction of river length that is reservoir

Width of river [M]

Area of river $[\mathrm{SQ} \mathrm{KM}]^{3}$

Area of connected low floodplain $[\mathrm{SQ} \mathrm{KM}]^{3}$

Area of reduced connectivity floodplain [SQ KM]

Area of valley bottom that is above floodplain or is road, levee, or railroad [SQ KM]

Fraction of FPU area with lidar data

Area of hillslopes greater than 30 degrees in the drainage area of the FPU [SQ KM]

Area of hillslopes with forest cover draining directly to FPU (SQ KM)

Area of basin with forest cover

Length of mainstem river with bull trout [KM]

Length of mainstem river in FPU with Chinook salmon [KM]

Length of mainstem river in FPU with steelhead trout [KM]

Length of mainstem river in and upstream of FPU with bull trout [KM]

Length of mainstem river in and upstream of FPU with Chinook salmon [KM]

Length of mainstem river in and upstream of FPU with steelhead trout [KM]

Length of non-mainstem river segments (tributaries, anabranches, side channels)

Number of non-mainstem river segments (tributaries, anabranches, side channels)
Area of connected high floodplain [SQ KM] $]^{3}$

Short name

FPU

DrAreaKM2

RivLenKM

Grad

DeltaGrad

Sinuosity

UnregFrac

ResFrac

RivWidM

RivKM2

FpLowConKM2

FpHighConKM2

FpRcKM2

NotFpKM2

LiDARcov

Slope30dKM2

ForcatchKM2

ForBasinKM2

BTLenKM

ChinLenKM

STLenKM

BTUpKM

ChinUpKM

STUpKM

OCH_num

$\mathrm{OCH}$-KM

] TEMP

FPU has a mainstem river segment listed as impaired for dissolved oxygen under Clean Water Act Section 303d DO

[1-yes, 0 -no]

FPU has a mainstem river segment listed as impaired for $\mathrm{pH}$ under Clean Water Act Section 303d [1- yes, 0 -no]

\footnotetext{
${ }^{1}$ Mainstem segments have a drainage area of at least $50 \mathrm{~km}^{2}$, headwater FPUs may have no or very short mainstem river lengths.

${ }^{2}$ Values are not available in FPUs with lidar coverage less than 90 percent because river area is not accurate.

${ }^{3}$ Gradients are not calculated for FPUs where mainstem length is less than $0.1 \mathrm{~km}$.
} 
Table 5. Indices of floodplain function and risk used in the geospatial assessment of ecological functions and flood-related risks on floodplains along major rivers, Puget Sound Basin, Washington.

\begin{tabular}{|c|c|c|}
\hline Description (units) & Short name & $\begin{array}{c}\text { Function, } \\
\text { hazard, or risk }\end{array}$ \\
\hline Floodplain unit & FPU & \\
\hline Width of connected floodplain (area/river length) $[\mathrm{M}]$ & FpConWidM & FN1 \\
\hline Width of reduced connectivity floodplain $[\mathrm{M}]$ & FpRcWidM & FN1 \\
\hline Ratio of width of river to square root of drainage area $[\mathrm{M} / \mathrm{M}]$ & RivAR & FN1 \\
\hline Ratio of width of connected floodplain to square root of drainage area $[\mathrm{M} / \mathrm{M}]$ & FpConAR & FN1 \\
\hline Ratio of width of reduced connectivity floodplain to square root of drainage area $[\mathrm{M} / \mathrm{M}]$ & FpRcAR & FN1 \\
\hline Conveyance index: product of river gradient and river width $[\mathrm{M}]$ & Convey & FN1, HAZ1 \\
\hline $\begin{array}{l}\text { Difference in conveyance index of FPU and sum of conveyance index for upstream, bordering } \\
\text { floodplain units }\end{array}$ & DeltaConvey & FN1, FN2, HAZ1, HAZ2 \\
\hline Ratio of width of connected, undeveloped floodplain to square root of drainage area & FpConUndAR & FN2 \\
\hline Ratio of width of reduced connectivity, undeveloped floodplain to square root of drainage area & FpRcUndAR & FN2 \\
\hline Ratio of width of connected, developed floodplain to square root of drainage area & FpConDevAR & FN2, HAZ1, EXP2 \\
\hline Fraction of river margin with forest cover & BankForFrc & FN2 \\
\hline Fraction of river margin undeveloped, not forest cover & BankUndFrc & FN2 \\
\hline Fraction of river margin developed & BankDevFrac & FN2, HAZ2, EXP2 \\
\hline Fraction of river margin with roads, levees, or railroads & BankRLRFrac & FN2, HAZ2, EXP3 \\
\hline $\begin{array}{l}\text { Floodplain width with wetland, hydric soil, or shallow groundwater; silt/clay }>30 \text { percent, } \\
\text { organic matter }>2 \text { percent }[\mathrm{M}]\end{array}$ & FpWetScOmW & FN3 \\
\hline $\begin{array}{l}\text { Floodplain width with wetland, hydric soil, or shallow groundwater; silt/clay }>30 \text { percent, } \\
\text { organic matter }<2 \text { percent }[\mathrm{M}]\end{array}$ & FpWetScW & FN3 \\
\hline $\begin{array}{l}\text { Floodplain width with wetland, hydric soil, or shallow groundwater; silt/clay }<30 \text { percent, } \\
\text { organic matter }<2 \text { percent }[\mathrm{M}]\end{array}$ & FpWetW & FN3 \\
\hline Connected, forested floodplain width $[\mathrm{M}]$ & FpConForW & FN4 \\
\hline Connected, undeveloped but not forested floodplain width $[\mathrm{M}]$ & FpConUndW & FN4 \\
\hline Reduced connectivity, forested floodplain width [M] & FpRcForW & FN4 \\
\hline Reduced connectivity, undeveloped, not forested floodplain width [M] & FpRcUndW & FN4 \\
\hline Fraction of areas draining directly to floodplain unit (not upstream units) that is forested & CatchForFrc & FN4 \\
\hline Areas of undeveloped river edge divided by mainstem river length & RivEdgeUndW & FN5 \\
\hline Connected floodplain width divided by river width & Confine & FN5 \\
\hline $\begin{array}{l}\text { Difference between confinement and potential confinement (combined width of connected } \\
\text { and reduced connectivity floodplain/river width) up to a potential confinement of } 4 \text { in } \\
\text { FPUs with confinement less than } 4 \text { [M/M] }\end{array}$ & AddConfine & FN5 \\
\hline
\end{tabular}

In cases where a function or risk is represented by an area-based measure (for example, the area of connected, forested floodplain in an FPU), the measure is divided by mainstem river length to produce a mean width of floodplain in the FPU with the function or risk. In cases where a function or risk depends on the interaction of factors, those factors are combined into an index (for example, river width and gradient are combined into an index of flood conveyance). Tables with the values of the attributes and indices for each FPU are available at http://pubs.usgs.gov/sir/2015/5033/ as part of this report (fpu_attribute.csv and fpu_indices.csv).
The relevance of the selected attributes and indices to function and risk is described briefly for context. The assessment does not provide an exhaustive set of attributes and indices that would be used in either a comprehensive or a targeted evaluation of ecological functions and risks to people on floodplains. Indices that integrate many factors influencing function or risk over large areas (for example, Hauer and Smith, 1998) were not derived as part of the coarse-scale assessment because of compounding uncertainty from source data, weighting of multiple factors, and spatial scaling. 


\section{Floodplain Functions}

\section{Function 1. Store and Convey Floods}

Floodplain storage and conveyance depend on the river and floodplain area available for flooding, the hydraulic gradient of the river during a flood, and the depth of water during a flood. The area of river, connected low floodplain, and connected high floodplain indicate the capacity available to store and convey flood waters in each FPU (table fpu_attributes.csv, variables RivKM2, FpLowCnKM2, and FpHighCnKM2, respectively). The area of reduced connectivity floodplain (table fpu_attributes.csv, variable FpRcKM2) indicates the potential to increase storage and conveyance through floodplain reconnection projects. The areas of rivers and floodplains are standardized by the length of mainstem river in each FPU to produce the mean widths of river, connected floodplain, and reduced connectivity floodplain for each FPU (table fpu_indices.csv, variables RivWidM, FpConWidM, FpRcWidM).

River and floodplains widths may be more useful than areas for comparisons of conditions across FPUs, but FPUs with higher streamflow can be expected to have wider rivers and floodplains. The non-dimensional ratios of river or floodplain width to the square root of drainage area (table fpu indices.csv, variables RivAR, FPConAR, FpRcAR) provide an index of the area of river or floodplain in an FPU that accounts for differences in the length of river and streamflow among FPUs. Width-area ratios can be used to identify FPUs that have relatively narrow or wide rivers or floodplains.

\section{Function 2. Regulate Sediment and Wood Supplies in River Networks}

The availability of sediments and coarse organic debris for transport depends on upstream sources of these materials and longitudinal connectivity between the source area and a floodplain. Dams disconnect source areas from downstream floodplains (table fpu_attributes.csv, variable UnregFrac). Areas with steep slopes, defined as greater than 30 degrees, in the unregulated portion of the drainage area of an FPU (table fpu_attributes.csv, variable Slop30dUpKM2) disproportionately contribute sediment to river networks. Steep, forested areas in unregulated portions of a river basin indicate the overall availability of wood supplies to a floodplain (table fpu_attributes.csv, variable ForCatchKM2. Land cover on river banks can affect the delivery of sediment and wood to rivers and may indicate the presence of bank protection structures that limit bank erosion. Land cover on banks is expressed in terms of the fraction of river bank cells with forest, undeveloped cover, developed cover, or with roads/levees/railroads (fpu_indices.csv, variables BankForFrc, BankUndFrc, BankDevFrc, BankRLRFrc).

\section{Function 3. Retain and Transform Nutrients and Contaminants}

Retention and transformation of water pollutants on floodplains require sources of pollutants, areas where the pollutants are stored in surface water, on the land surface, or sorbed to sediments. Retention of particulates and compounds sorbed to particulates is most likely in low gradient valley segments (table fpu_attributes.csv, variable Grad). The area of floodplain with indicators of anaerobic conditions, finegrained sediments, and high organic matter as defined in the fine-scale assessment may indicate the capacity of the floodplain to retain and transform nutrients and contaminants. The areas in each FPU with these factors were divided by the length of mainstem river in each FPU to produce the width of floodplains with anaerobic indicators (table fpu_indices.csv, variable FpWetW), with anaerobic indicators and fine-grained sediments (variable FpWetScW), and these factors plus high organic matter (variable FpWetScOmW).

\section{Function 4. Support Forest Ecosystems}

The extent of connected and reduced connectivity floodplain forests are expressed as mean widths for each FPU (table fpu_indices.csv, variables FpConForW and FpRcForW, respectively). Undeveloped areas that could potentially support forest on connected floodplains and reduced connectivity floodplains also are expressed in terms of mean widths for each FPU (table fpu indices.csv, variables FpConUndW and FpRcUndW). Floodplain forests can be part of larger forest ecosystems that extend across valleys, serving as migration corridors and ecotones between terrestrial and aquatic habitats. Given the intensity of land use on floodplains, fragmentation of floodplain forests may be a significant source of fragmentation of larger forest ecosystems. As a result, the fraction of forest cover on hillslopes draining directly to an FPU, but not including areas that drain to upstream FPUs, (table fpu_indices.csv, variable CatchForFrc) provides a measure of the potential value of an FPU in maintaining connectivity across a larger forest ecosystem.

\section{Function 5. Provide Aquatic Habitats}

Floodplain-river systems are a mosaic of different habitats distinguished by their connectivity to a river in time and space and the seral stage of vegetation on the floodplain (Ward and others, 2002; Konrad and others, 2011). In the Pacific Northwest, the diversity of aquatic habitats on a floodplain and the presence of complex habitat types are associated with reach-scale plan form of river channels (straight, meandering, anastomosing, island-braided, braided), which depends in part on valley gradient and confinement (Beechie and others, 2006). 
Confinement is the ratio of valley or floodplain width to river width (Knighton, 1998). When a floodplain is about twice as wide as a river channel (confinement greater than 3 ), the river is largely unconfined by its valley and displays functional differences including greater retention of organic material and greater biodiversity (Bellmore and Baxter, 2013). Unconfined rivers can inundate large areas during and after floods that provide aquatic habitats, migrate to new locations and create off-channel aquatic habitats at the former location of the channel, and support complex food webs that include anadromous salmonids (Beechie and others, 2006; Konrad and others, 2008; Konrad, 2012; Bellmore and others, 2013). Rivers with confinement less than 3 typically have a single channel with a limited number and area of off-channel aquatic habitats (Bellmore and Baxter, 2013). Rivers can be confined with little or no floodplain because: their valley is relatively narrow; they are incised into valley fill deposits and have not developed a floodplain since incision; or they are disconnected from their floodplain by roads, railroads, levees, or other structures. The potential to reduce anthropogenic confinement of a river can be estimated as the difference between the confinement calculated using connected floodplain width and confinement calculated using connected and disconnected floodplain width (table fpu_indices.csv, variable AddConfine).

Although the current and potential complexity of aquatic habitats is likely to be related to confinement, the length of mainstem channels in an FPU provide an index of its complexity incorporating both meander bends (which indicate pool-riffle morphology) and islands, which provide additional edge habitats. The length of mainstem channel divided by its straight-line distance, or sinuosity, (table fpu_attributes.csv, variable Sinuosity) provides an index of mainstem habitat complexity that can be compared among FPUs.

Upstream sources of sediment and wood contribute to the development of complex aquatic habitats (table fpu_attributes. csv, variables Slp30degKM2, ForCatchKM2, ForBasinKM2). In addition to mainstem river segments, tributaries, anabranches, and side channels (table fpu_attributes.csv, $\mathrm{OCH}$ _num and $\mathrm{OCH}$ _KM) represent other significant large habitat features in river networks (Beechie and others, 2006; Rice and others, 2006). River edges (fpu_indices.csv, variable RivEdgeUndW) are particularly important rearing areas for juvenile salmonids because of shallow, low velocity streamflow (Beechie and others, 2005).

The significance of floodplains to salmonids depends in part on production of juveniles in the river network. The total length of stream in an FPU and upstream of an FPU with bull trout, steelhead trout, and Chinook salmon (table fpu attributes.csv, variables BTLenKM, BTUpKM, STLenKM, STUpKM, and ChinLenKM, ChinUpKM) serves as a gross index to represent variation across FPUs in the number of juvenile salmonids that could use floodplain habitats.

Salmonid production can be limited by water quality in rivers or streams draining to Puget Sound (Marshall and others, 2014). FPUs with river segments listed as impaired for temperature, dissolved oxygen, or $\mathrm{pH}$ (Washington State Department of Ecology, 2012) (table_fpu_attributes.csv, variables TEMP, DO, $\mathrm{pH}$ ) may have reduced capability to support salmonids.

\section{Flood-Related Hazards}

Flood inundation hazard is most likely in low-lying, low gradient areas (table fpu_attribute, variables FpLowCnKM2 and $\mathrm{Grad}$ ) along rivers with a large, unregulated fraction of their drainage area (table fpu_attribute, variable UnregFrc). Channel occupation (hazard 2) is associated with highgradient rivers (table fpu_attribute, variable Grad), high sediment loads (table fpu_attribute, variable Slope30dKM2), and a downstream reduction in gradient (table fpu_attributes. csv, variable DeltaGrad) or conveyance (table fpu_indices. csv, variable DeltaConvey). Floodplain units where DeltaGrad or DeltaConvey are less than 0 indicate a decreasing capacity of the river to convey floods and the potential for higher stages, sediment deposition in these reaches, and an increasing probability of channel avulsion (Collins and Montgomery, 2011).

\section{Flood-Related Exposure}

The ratio of connected, developed floodplain width to the square root of drainage area (table fpu.indices.csv, variable FpConDevAR) provides a general index of exposure of residential, agricultural, and other commercial development to flooding.

\section{Overview of Assessment Outputs}

The Puget Sound Basin has extensive river-floodplain systems in its major valleys. These systems cover about $1,600 \mathrm{~km}^{2}$ including rivers (about one-fourth of system area), low floodplains (about three-eighths of system area) and three-eighths high floodplains (about three-eighths of system area) (table 4). Large river deltas, which can be many kilometers wide, comprise most of the floodplain area. The FPU median floodplain width is $222 \mathrm{~m}$.

Floodplain connectivity indicates a broad range of ecological functions including the current and potential capacity of floodplains to store and convey floods, transport sediment and wood, retain and transform water pollutants, support forest ecosystems, and provide habitats for aquatic species including endangered salmonids. Almost one-half of all floodplain areas $\left(743 \mathrm{~km}^{2}\right)$ in the Puget Sound have been disconnected to some extent from their rivers by roads, levees, and railroads (fig. 3), but disconnection is concentrated in lowland areas where floodplains generally are wider. 


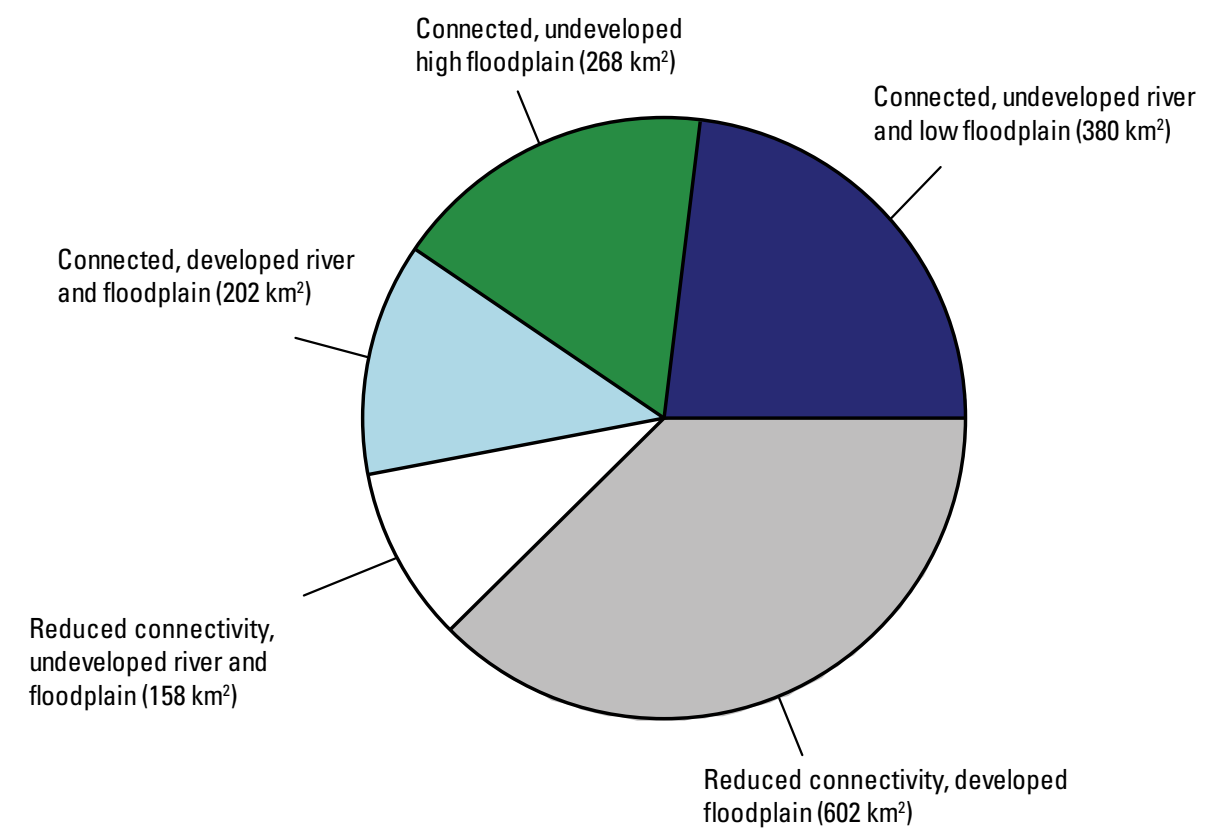

Figure 3. Connectivity and development of floodplains in Puget Sound Basin, Washington. Development includes impervious, developed non-impervious, and agricultural areas.

As a consequence, disconnection is much less prevalent in terms of the percent of river length than percent of floodplain area. Indeed, the FPU median width of connect floodplain is $199 \mathrm{~m}$ (table floodplain indices, variable FpConWidM) and 174 of 535 FPUs have no disconnection of floodplain areas.

Regulation of rivers by dams also affects floodplain connectivity in the Puget Sound Basin-10 percent of floodplains units, 10 percent of major river length $(281 \mathrm{~km})$, and 7 percent of floodplain area $\left(108 \mathrm{~km}^{2}\right)$ have more than 50 percent of their drainage area regulated. The effect of regulation, however, depends on dam operations and reservoir capacity and is beyond the scope of this assessment.

Most $\left(1,084\right.$ of $\left.1,603 \mathrm{~km}^{2}\right)$ of the floodplains delineated in for this assessment are considered "Special Flood Hazard Areas" with an annual probability of flooding of greater than 1 percent per year. Floodplain areas outside of the SFHA $\left(521 \mathrm{~km}^{2}\right)$ are in rural areas where SFHAs have not been delineated, are protected from flooding by levees, or otherwise have an annual probability of flooding of less than 0.01 . SFHAs include an additional $264 \mathrm{~km}^{2}$ outside of the floodplains delineated for this assessment, most of which is lake or reservoir. The lower Stillaguamish River valley and Snoqualmie River valley downstream of the Tolt River and around Falls City have the largest SFHAs that are not delineated as floodplains in this assessment. In these river segments, the increase in stage during large floods may be greater than estimated from the regional relation (fig. 2). Development on $196 \mathrm{~km}^{2}$ of connected floodplains represents risks to many people in the region who rely on connected floodplain for agriculture $\left(176 \mathrm{~km}^{2}\right)$ and who live, work, or travel in connected floodplains with medium and high development (14 km²) (table 6).

Anthropogenic confinement of rivers indicates where floodplain reconnection could improve ecological function and reduce flood risk. The ratio of connected floodplain width to the square root of drainage area (variable FpConAR) provides a metric of the extent of floodplains while accounting for river size. The median value for floodplains in the Puget Sound Basin is 0.01 , which represents a $100-\mathrm{m}$ wide connected floodplain for a river that has a drainage area of $100 \mathrm{~km}^{2}$ and a 300-m wide connected floodplain for a river that has a drainage area of $900 \mathrm{~km}^{2}$ (fig. 4). 
Table 6. Summary of floodplain connectivity and land use resulting from the geospatial assessment of ecological functions and flood-related risks on floodplains along major rivers, Puget Sound Basin, Washington.

[Land use based on National Land Cover Database 2011 land cover categories (National Oceanic and Atmospheric Administration, 2014). Agricultural use based on tax parcel designation (Washington State Department of Ecology, 2012)]

\begin{tabular}{lcccc}
\hline \multirow{1}{*}{ Flood plain connectivity } & \multicolumn{3}{c}{ Land use, in square kilometers } \\
\cline { 2 - 5 } & Total area & $\begin{array}{c}\text { Undeveloped } \\
\text { area }\end{array}$ & $\begin{array}{c}\text { Area of medium/ } \\
\text { high development }\end{array}$ & $\begin{array}{c}\text { Agricultural } \\
\text { area }\end{array}$ \\
\hline Connected floodplain including river areas & 850 & 648 & 14 & 176 \\
Connected high floodplain & 406 & 268 & 11 & 109 \\
Connected low floodplain and river & 444 & 380 & 4 & 67 \\
Connected low floodplain & 252 & 200 & 2 & 53 \\
Connected river & 192 & 180 & 1 & 14 \\
Reduced connectivity floodplain & 760 & 158 & 89 & 406 \\
Total floodplain and river & 1,610 & 806 & 103 & 581 \\
\hline
\end{tabular}

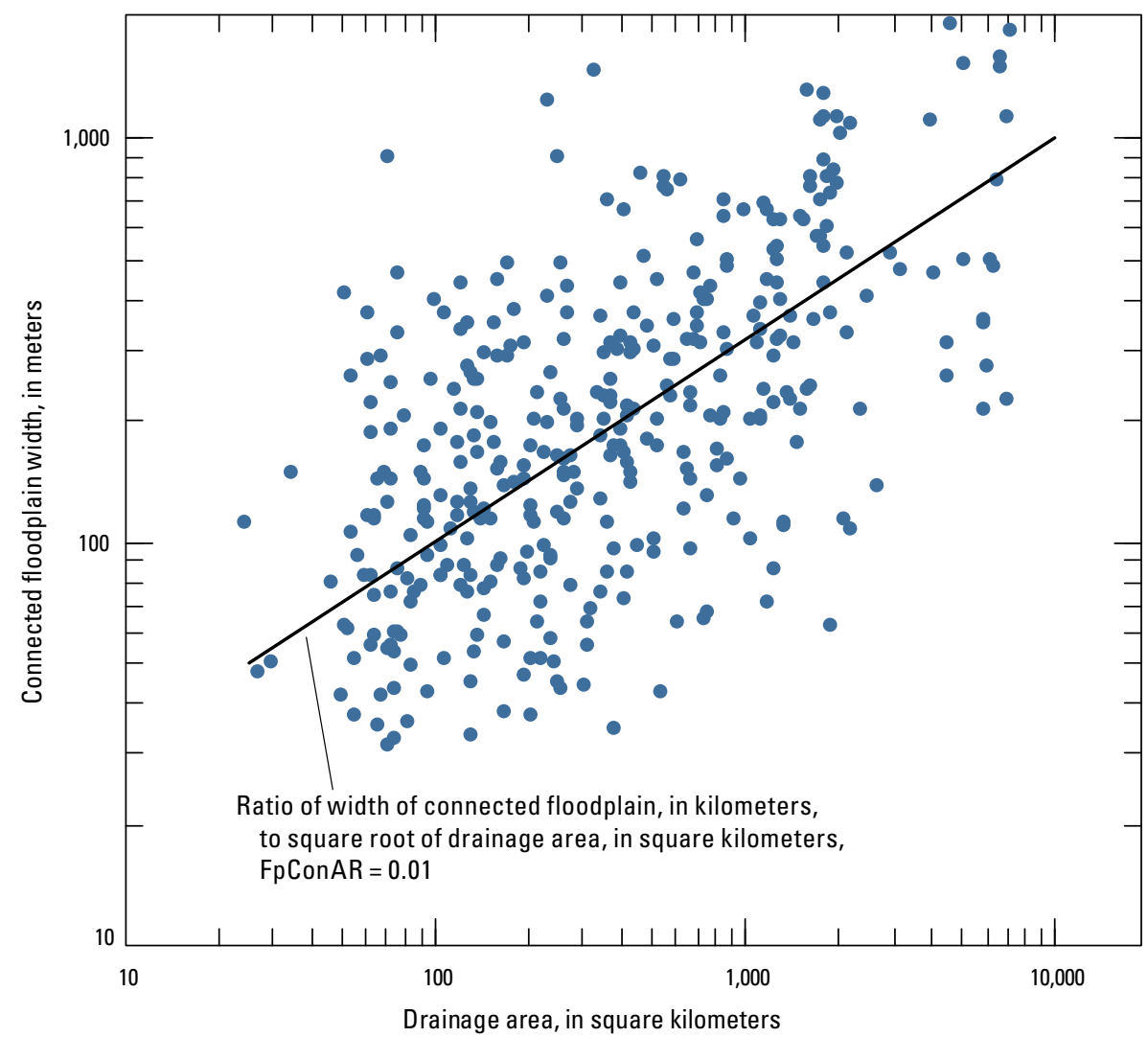

Figure 4. Width of connected floodplain area as a function of drainage area for mainstem rivers in the Puget Sound Basin, Washington. Line represents the median ratio of floodplain width to the square root of drainage area $\left(W=10\right.$ Area $\left.^{0.5}\right)$ for connected floodplains in the Puget Sound Basin. Relatively wide connected floodplains plot above the line, relatively narrow connected floodplains plot below the line. 
Ecological functions of connected floodplains that are at least three times the river width are distinct from narrower floodplains (see Bellmore and Baxter, 2013). Although some river valleys are too narrow to allow the development of wide floodplains, about one-half by length of the major rivers in the Puget Sound Basin are in valleys where floodplains (connected and reduced connectivity) are more than three times as wide as their channel (fig. 5). Roads, railroads, and levees have confined about $760 \mathrm{~km}$ of these rivers to connected floodplains less than three times as wide as their channels. The loss of unconfined rivers is of particular ecological significance because they support complex habitats including islands, side channels, wetlands, and provide shallower, low velocity edge habitat than confined rivers (Beechie and others, 2006; Konrad and others, 2008).

In addition to confining rivers, roads, levees and railroad have fragmented floodplains into smaller areas that limit the flow of water, transport of materials, and migration of organisms across floodplains. Prior to construction of this infrastructure, most floodplains in Puget Sound were in contiguous areas of at least $100 \mathrm{~km}^{2}$ (fig. 6). Currently, most floodplains are in fragments less than $10 \mathrm{~km}^{2}$.

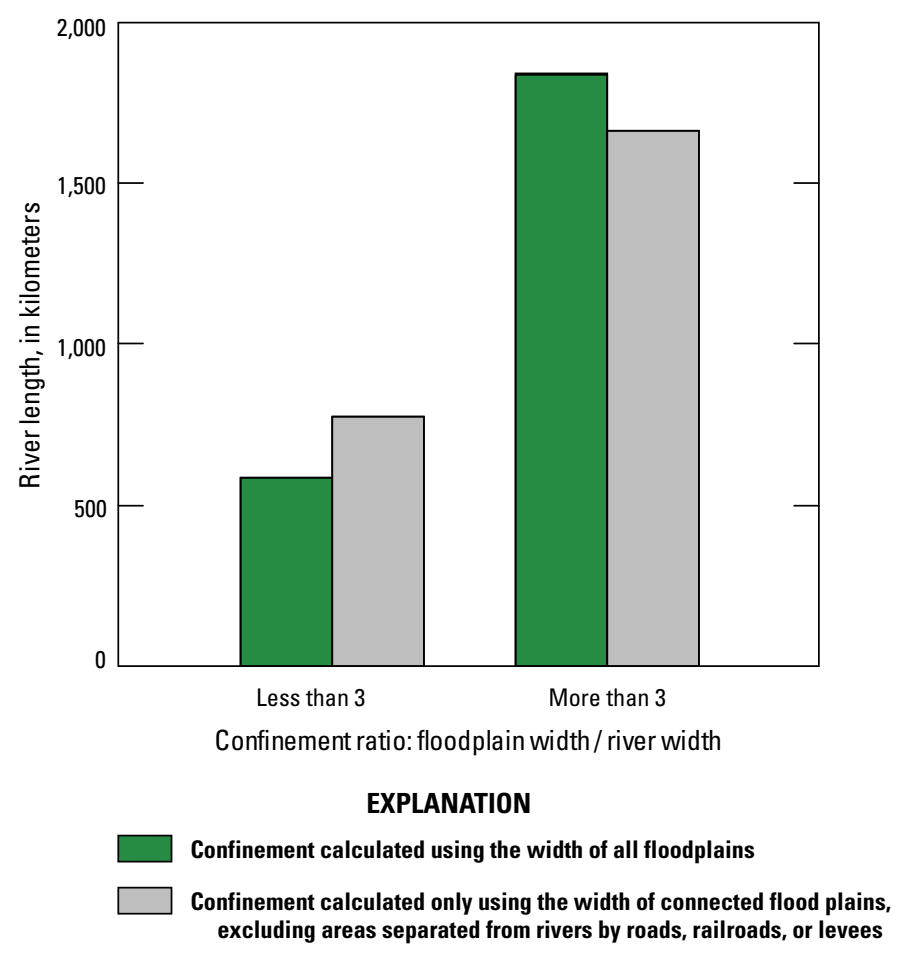

Figure 5. Length of confined and unconfined mainstem rivers in the Puget Sound Basin, Washington.

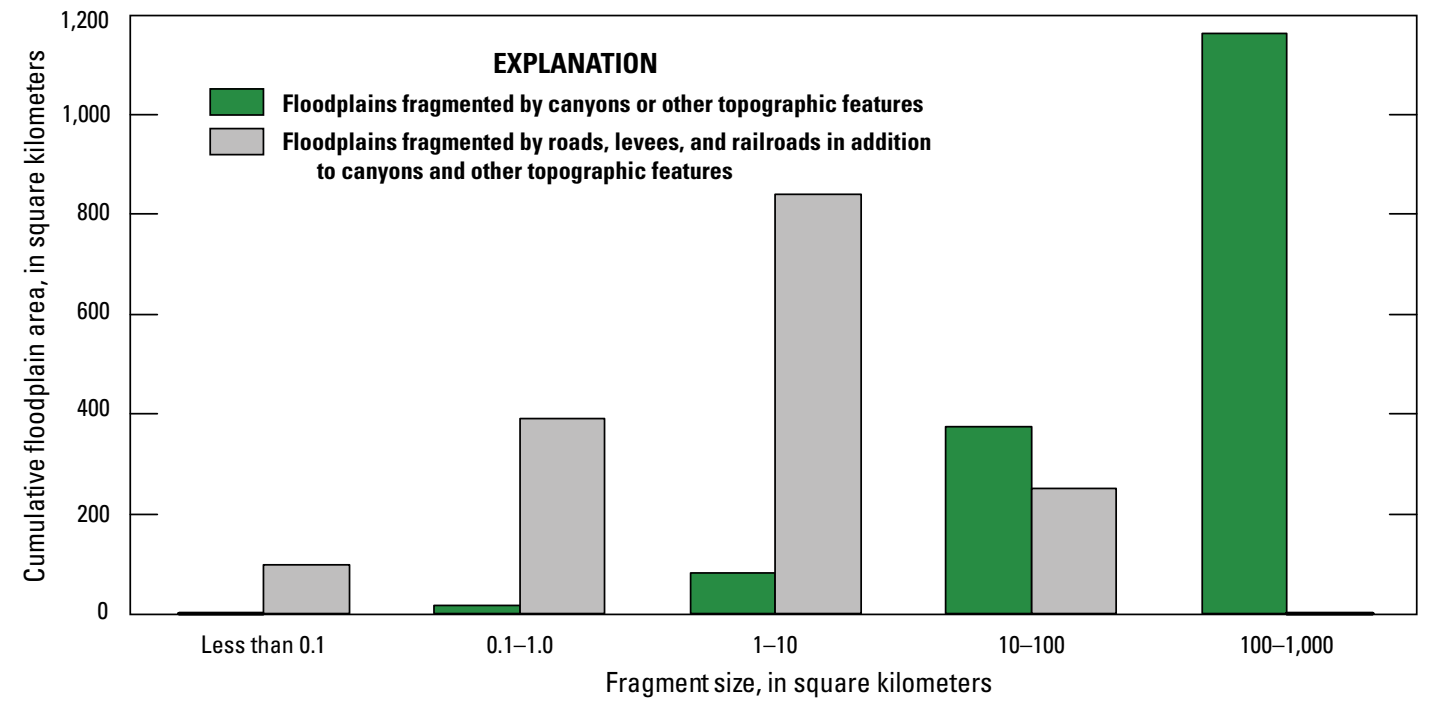

Figure 6. Cumulative floodplain area for fragment sizes, Puget Sound Basin, Washington. 


\section{Summary}

Ecological functions and flood-related risks were assessed for areas along the 17 major rivers in the Puget Sound Basin. For the fine-resolution assessment, available source data and simple GIS models were used to derive categories of function and risk as raster outputs with a 10 -meter resolution. These categories can be used to identify likely factors that would have to be addressed to recover floodplain function or reduce flood risk at a given location. In general, connectivity and land cover/land use are the primary attributes that influence ecological function and risk to people on floodplains. Both connectivity and land cover/land use would have to be addressed to improve function and reduce risk on most floodplains.

Attributes influencing floodplain function and risk were summarized for larger-scale floodplain units in the coarse-resolution assessment. The coarse-resolution assessment also includes indices that have been standardized to permit comparison between floodplain units of different areas and drainage areas. The attributes and indices from the coarse-resolution assessment can be combined to identify areas where ecological function can be improved and risks to people can be reduced. This is one step in the development of feasible objectives for integrated floodplain management for the Puget Sound region.

The assessment outputs are available as geospatial datasets in Konrad (2015; http://dx.doi.org/10.5066/ F7DR2SJC). The uncertainty in the outputs is determined by source data and the steps used to derive the datasets. All outputs have uncertainty around the boundaries of floodplains, which are based on spatial extrapolation of the approximate water- surface elevation of rivers and assumptions about the increase in those elevations during floods. In general, functions that integrate many factors, such as transforming nutrients and contaminants or providing aquatic habitats, have greater uncertainty. These functions also are affected by finescale heterogeneity in those factors, which introduces more uncertainty in the results.

In many cases, a more general assessment of floodplain function and risk using less derived information, such as connectivity and land cover, may be sufficient and more reliable for planning and management of floodplains. More than one-half of the floodplains along major rivers in the Puget Sound Basin have been disconnected to some extent by roads, levees, and railroads or have been developed for agricultural, other commercial, residential, or transportation uses. Ecological functions are likely impaired on these floodplains and there are likely to be flood-related risks to the people using these floodplains. In general, the most feasible opportunities to improve floodplain function may be in areas that either have been disconnected or developed, but not both. Likewise, the greatest opportunities to reduce risk may be in connected floodplain areas with development.

\section{Acknowledgments}

The U.S. Geological Survey received funding for this assessment from The Nature Conservancy through the Washington State Department of Ecology and U.S. Environmental Protection Agency's National Estuary Program. Theresa Olsen, U.S. Geological Survey, assisted with compiling and analyzing geospatial data. This assessment incorporates contributions from many people including: Allison Bailey, Sound GIS, Jack Barbash, U.S. Geological Survey; Tim Beechie, National Oceanic and Atmospheric Administration; Bob Black, U.S. Geological Survey; Derek Booth, Stillwater Sciences; Scott Campbell, U.S. Army Corps of Engineers; Bob Carey, The Nature Conservancy; Brian Collins, University of Washington; Paula Cooper, Whatcom Co.; Steve Cox, U.S. Geological Survey; Paul Cereghino, National Oceanic and Atmospheric Administration; Dennis Dixon, Pierce Co.; Susan Grigsby, Washington State Department of Ecology; Polly Hicks, National Oceanic and Atmospheric Administration; Hans Hunger, Pierce Co.; Colin Hume, Washington State Department of Ecology; Kris Johnson, The Nature Conservancy; Nick Legg, Washington State Department of Ecology; Rand Little, Seattle Public Utilities; Julie Morse, The Nature Conservancy; Mark Munn, U.S. Geological Survey; Patricia Olson, Washington State Department of Ecology; Lorin Reinhelt, King County; Kelly Slattery, Washington State Department of Ecology; Stephen Stanley, Washington State Department of Ecology; Kelly Stone, Federal Emergency Management Agency; David St. John, Puget Sound Partnership; Jim Tesoriero, U.S. Geological Survey; and Christian Torgersen, U.S. Geological Survey.

\section{References Cited}

Baldwin, D.S., and Mitchell, A.M., 2000, The effects of drying and re-flooding on the sediment and soil nutrient dynamics of lowland river-floodplain systems-A synthesis: Regulated Rivers-Research and Management, v. 16, no. 5, p. 457-467.

Beechie, T.J., Liermann, M., Beamer, E.M., and Henderson, R., 2005, A classification of habitat types in a large river and their use by juvenile salmonids: Transactions of the American Fisheries Society, v. 134, p. 717-729.

Beechie, T.J., Liermann, M., Pollock, M.M., Baker, S., and Davies, J., 2006, Channel pattern and riverfloodplain dynamics in forested mountain river systems: Geomorphology, v. 78, p. 124-141. 
Bellmore, J.R., and Baxter, C.V., 2013, Effects of geomorphic process domains on river ecosystems: a comparison of floodplain and confined valley segments, River Research and Applications, v. 30, p. 617-630.

Bellmore, J.R., Baxter, C.V., Martens, K., and Connolly, P.J., 2013, The floodplain food web mosaic - A study of its importance to salmon and steelhead with implications for their recovery: Ecological Applications, v. 23, p. 189-207.

Chow, V.T., 1959, Open-channel hydraulics: New York, McGraw-Hill, 680 p.

Collins B.D., and Montgomery, D.R., 2011, The legacy of Pleistocene glaciation and the organization of lowland alluvial process domains in the Puget Sound region: Geomorphology, v. 126, p. 174-185.

Environmental Systems Research Institute, 2013, ArcGIS Desktop 10 Service Pack 5.

Federal Emergency Management Agency, 2013, Flood map service center, accessed January 27, 2013, at https://msc. fema.gov/portal.

Fetherston, K.L, Naiman, R.J., and Bilby, R.E., 1995, Large woody debris, physical process, and riparian forest development in montane river networks of the Pacific Northwest: Geomorphology, v. 13, p. 133-144.

Hauer, F.R, and Smith, R.D., 1998, The hydrogeomorphic approach to functional assessment of riparian wetlandsEvaluating impacts and mitigation on river floodplains in the U.S.A.: Freshwater Biology, v. 40, p. 517-530.

Hickin, E.J., and Nanson, G.C., 1984, Lateral migration rates of river bends: Journal of Hydraulic Engineering, v. 110, p. 1,557-1,567.

Hooke, J.M., 1980, Magnitude and distribution of rates of river bank erosion: Earth Surface Processes, v. 5, p. 143-157.

Jones, J., 2006, Side channel mapping and fish habitat suitability analysis using Lidar topography and orthophotography: Photogrammetric Engineering and Remote Sensing, v. 72, no. 11, p. 1,202-1,206.

Kleinhans, M.G., de Hhas, T., Lvooi, E., and Makaske, B., 2012, Evaluating competing hypotheses for the origins and dynamics of river anastomosis: Earth Surface Processes and Landforms, v. 37, p. 1,337-1,351.

Knighton, D., 1998, Fluvial forms and processes: London, Arnold Publishers, $383 \mathrm{p}$.

Konrad C.P., 2012, Reoccupation of floodplains by rivers and its relation to the age structure of floodplain vegetation: Journal of Geophysical Research, v. 117, no. G00N13.
Konrad, C.P., 2015, Geospatial data on ecological functions and flood-related risks to people on major river floodplains in the Puget Sound Basin, Washington: U.S. Geological Survey data release, http://dx.doi.org/10.5066/F7DR2SJC.

Konrad, C., Berge, H., Fuerstenberg, R., Steff, K., Olsen, T., and Guyenet, J., 2011, Channel dynamics in the Middle Green River, Washington, from 1936-2002: Northwest Science, v. 85, p. 1-14.

Konrad, C.P., Black, R.W., Voss, F., and Neale, C.M.U., 2008, Integrating remotely acquired and field data to assess effects of setback levees on riparian and aquatic habitats in glacial-melt water rivers: River Research and Applications, v. 24 , no. 4 , p. 355-372.

Latterell, J.J., Bechtold, J.S., O’Keefe, T.C., van Pelt, R., and Naiman, R.J., 2006, Dynamic patch mosaics and channel movement in an unconfined river valley of the Olympic Mountains: Freshwater Biology, v. 51, p. 523-544.

Marcus, W.A., 1989, Regulating contaminated sediments in aquatic environments-A hydrologic perspective: Environmental Management, v. 13, p. 703-713.

Marshall, R., Era-Miller, B, and Collyard, S., 2014, Integrated ambient monitoring follow-up study in Indian Creek: an investigation of the causes of biological impairment and a further demonstration of the instream monitoring approach: Washington State Department of Ecology, Publication No. 14-03-050.

Naiman, R.J., Bechtold, J.S., Beechie, T.J., Latterell, J.J., and van Pelt, R., 2010, A process-based view of floodplain forest pattern in coastal river valleys of the Pacific Northwest: Ecosystems, v. 13, p. 1-31.

Nanson, G.C., and Croke, J.C., 1992, A genetic classification of floodplains: Geomorphology, v. 4, p. 459-486.

Nanson, G.C., and Hickin, E.J., 1986, A statistical examination of bank erosion and channel migration in western Canada: Bulletin of the Geological Society of America, v. 97, p. 497-504.

Nanson, G.C., and Knighton, A.D., 1996, Anabranching rivers: their cause, character, and classification: Earth Surface Processes and Landforms, v. 21, p. 217-239.

National Oceanic and Atmospheric Administration, 2014, 2010 Coastal change analysis program regional land cover Washington, accessed April 25, 2014, at http:/www.csc. noaa.gov/htdata/ccap/ccap_regional_dates/wa_2011_ccap_ land_cover.zip.

National Research Council, 1992, Restoration of aquatic ecosystems - Science, technology, and public policy, water science and technology board: Washington D.C., National Academy Press, 552 p. 
National Resource Conservation Service, 2013, SSURGO Database, accessed March 11, 2014, at http://websoilsurvey. sc.egov.usda.gov/App/HomePage.htm.

Olson, P.L., Legg, N.T., Abbe, T.B., Reinhart, Mary Ann, and Radloff, J.K., 2014, A methodology for delineating planning-level channel migration zones: Olympia, Washington, Shorelands and Environmental Assistance Program, Washington State Department of Ecology, Publication No. 14-06-025, 83 p.

Orr, C.H., Stanley, E.H., Wilson, K.A., and Finlay, J.C., 2007, Effects of restoration and reflooding on soil denitrification in a leveed midwestern floodplain: Ecological Applications, v. 17, p. 2,365-2376, http://dx.doi.org/10.1890/06-2113.1

Pinay, G., Black, V.J., Planty-Tabacchi, A.M., Gumiero, B., and Decamps, H., 2000, Geomorphic control on denitrification in large river floodplain soils: Biogeochemistry, v. 50, p. 163-182.

Pinay, G., Clement, J.C., and Naiman, R.J., 2002, Basic principles and ecological consequences of changing water regimes on nitrogen cycling in fluvial systems: Environmental Management, v. 30, p. 481-491.

Puckett, L.J., Zamora, C., Essaid, H., Wilson, J.T., Johnson, H.M., Brayton, M.J., and Vogel, J.R., 2008, Transport and fate of nitrate at the ground-water-surface-water interface: Journal of Environmental Quality, v. 37, p. 1,034-1,050.

Puget Sound Lidar Consortium, 2011, Puget Sound Lidar supermosaic, http://pugetsoundlidar.ess.washington.edu/.

Rapp, C., and Abbe, T., 2003, A framework for delineating channel migration zones: Washington State Department of Ecology Report 03-06-027, 135 p.

Rice, S.P., Ferguson, R.I., and Hoey, T.B., 2006, Tributary control of physical heterogeneity and biological diversity at river confluences: Canadian Journal of Fisheries and Aquatic Sciences, v. 63, p. 2,553-2,566.

Slingerland, R., and Smith, N.D., 2004, River avulsions and their deposits: Annual Reviews of Earth and Planetary Science, v. 32, p. 257-285.

Smith, J.A., Wikowski, P.J., and Fusillo, T.V., 1988, Manmade organic compounds in the surface waters of the United States-A review of current understanding: U.S. Geological Survey Circular 1007, 104 p.

Tesoriero, A.J., and Puckett, L.J., 2011, O2 reduction and denitrification rates in shallow aquifers: Water Resources Research, v. 47, no. W12522, 17 p., doi:10.1029/2011WR010471.

U.S. Army Corps of Engineers, 2013, National levee database, accessed March 11, 2014, at http://nld.usace.army.mil/ egis/f?p=471:1:
U.S. Army Corps of Engineers, 2014, Skagit River flood risk management general investigation, Skagit County, Washington-Draft feasibility report and environmental impact statement-Appendix B: Hydraulics and Hydrology, 478 p., http://www.nws.usace.army.mil/Portals/27/docs/ civilworks/projects/Skagit\%20GI/SkagitGI-AppB-HHMAY2014.pdf.

U.S. Census Bureau, 2010, Washington primary and secondary roads, accessed September 24, 2014, at http://geography. wa.gov/data-products-services/data/data-catalog.

U.S. Geological Survey, 2012, National elevation dataset, $10 \mathrm{~m}$, accessed on March 11, 2014, at http://ned.usgs.gov/.

U.S. Geological Survey, 2013, National hydrography dataset high resolution hydrography, accessed April 25, 2014, at ftp://nhdftp.usgs.gov/DataSets/Staged/States/FileGDB/ HighResolution/NHDH_WA_931v210.zip.

U.S. Geological Survey, 2014, National land cover database 2011 percent developed imperviousness, http://www.mrlc. gov/nlcd11_data.php.

Ward, J.V., and Stanford, J.A., 1995, The serial discontinuity concept-Extending the model to floodplain rivers: Regulated Rivers-Research and Management, v. 10, p. $159-168$.

Ward, J.V., Tockner, K., Arscott, D.B., and Claret, C., 2002, Riverine landscape diversity: Freshwater Biology, v. 47, p. 517-539.

Washington Department of Fish and Wildlife, 2013, Distributions of Chinook salmon, steelhead trout, and bull trout, accessed March 11, 2014, at http://apps.wdfw.wa.gov/ salmonscape/map.html.

Washington Department of Health, 2013, Water systems, septic systems, fire stations, hospitals, emergency medical services, accessed September 24, 2014, at http://geography. wa.gov/data-products-services/data/data-catalog.

Washington Department of Natural Resources, 2010, Surface geology 1:100,000, accessed September 24, 2014, at http:// geography.wa.gov/data-products-services/data/data-catalog.

Washington Department of Transportation, 2013, Railroads 1:24,000, accessed September 24, 2014, at http://geography. wa.gov/data-products-services/data/data-catalog.

Washington State Department of Ecology, 2010a, Statewide levee inventory and flood protection study-Report on certification and accreditation: Bellingham, Wash., Western Washington University, prepared by the Resilience Institute, publication number 10-06-029, 123 p., accessed September 24, 2014, at https://fortress.wa.gov/ecy/ publications/publications/1006029.pdf. 
Washington State Department of Ecology, 2010b, Washington state land use, accessed May 17, 2014, at http://www.ecy. wa.gov/services/gis/data/planningCadastre/landuse.htm.

Washington State Department of Ecology, 2012, Washington water quality assessment 303(d), accessed May 17, 2014, at http://www.ecy.wa.gov/services/gis/data/data.htm.

Washington State Department of Ecology, 2013a, Puget Sound watershed characterization, accessed May 17, 2014, at http://www.ecy.wa.gov/services/gis/data/pugetsound/ characterization.htm.
Washington State Department of Ecology, 2013b, Permit and reporting information system, accessed April 25, 2014, at http://www.ecy.wa.gov/PROgrams/wq/permits/paris/index. html.

Wolman, M.G., and Leopold, L.B., 1957, River flood plainsSome observations on their formation: U.S. Geological Survey Professional Paper 282-C, p. 87-109. 
Publishing support provided by the U.S. Geological Survey

Science Publishing Network, Tacoma Publishing Service Center

For more information concerning the research in this report, contact the Director, Washington Water Science Center

U.S. Geological Survey

934 Broadway, Suite 300

Tacoma, Washington 98402

http://wa.water.usgs.gov 
